\title{
Depositional Environments for Strata of Composite Section of Frontier Formation, Madison Range, Southwestern Montana
}

\section{U.S. GEOLOGICAL SURVEY BULLETIN 1949}




\section{AVAILABILITY OF BOOKS AND MAPS OF THE U.S. GEOLOGICAL SURVEY}

Instructions on ordering publications of the U.S. Geological Survey, along with prices of the last offerings, are given in the current-year issues of the monthly catalog "New Publications of the U.S. Geological Survey." Prices of available U.S. Geological Survey publications released prior to the current year are listed in the most recent annual "Price and Availability List." Publications that are listed in various U.S. Geological Survey catalogs (see back inside cover) but not listed in the most recent annual "Price and Availability List" are no longer available.

Prices of reports released to the open files are given in the listing "U.S. Geological Survey Open-File Reports," updated monthly, which is for sale in microfiche from the U.S. Geological Survey, Books and Open-File Reports Section, Federal Center, Box 25425, Denver, CO 80225. Reports released through the NTIS may be obtained by writing to the National Technical Information Service, U.S. Department of Commerce, Springfield, VA 22161; please include NTIS report number with inquiry.

Order U.S. Geological Survey publications by mail or over the counter from the offices given below.

\section{BY MAIL}

\section{Books}

Professional Papers, Bulletins, Water-Supply Papers, Techniques of Water-Resources Investigations, Circulars, publications of general interest (such as leaflets, pamphlets, booklets), single copies of Earthquakes \& Volcanoes, Preliminary Determination of Epicenters, and some miscellaneous reports, including some of the foregoing series that have gone out of print at the Superintendent of Documents, are obtainable by mail from

\section{U.S. Geological Survey, Books and Open-File Reports Federal Center, Box 25425 Denver, CO 80225}

Subscriptions to periodicals (Earthquakes \& Volcanoes and Preliminary Determination of Epicenters) can be obtained ONLY from the

\section{Superintendent of Documents \\ Government Printing Office \\ Washington, D.C. 20402}

(Check or money order must be payable to Superintendent of Documents.)

\section{Maps}

For maps, address mail orders to

\section{U.S. Geological Survey, Map Distribution \\ Federal Center, Box 25286 \\ Denver, CO 80225}

Residents of Alaska may order maps from

\author{
Alaska Distribution Section, U.S. Geological Survey, \\ New Federal Building - Box 12 \\ 101 Twelfth Ave., Fairbanks, AK 99701
}

\section{OVER THE COUNTER}

\section{Books}

Books of the U.S. Geological Survey are available over the counter at the following Geological Survey Public Inquiries Offices, all of which are authorized agents of the Superintendent of Documents:

- WASHINGTON, D.C.--Main Interior Bldg., 2600 corridor, 18 th and C Sts., NW.

- DENVER, Colorado--Federal Bldg., Rm. 169, 1961 Stout St.

- LOS ANGELES, California--Federal Eldg., Rm. 7638, 300 N. Los Angeles St.

- MENLO PARK, California--Bldg. 3 (Stop 533), Rm. 3128, 345 Middlefield Rd.

- RESTON, Virginia--503 National Center, Rm. 1C402, 12201 Sunrise Valley Dr.

- SALT LAKE CITY, Utah--Federal Bldg., Rm. 8105, 125 South State St.

- SAN FRANCISCO, California--Customhouse, Rm. 504, 555 Battery St.

- SPOKANE, Washington--U.S. Courthouse, Rm. 678, West 920 Riverside Ave..

- ANCHORAGE, Alaska--Rm. 101, 4230 University Dr.

- ANCHORAGE, Alaska--Federal Bldg, Rm. E-146, 701 C St.

\section{Maps}

Maps may be purchased over the counter at the U.S. Geological Survey offices where books are sold (all addresses in above list) and at the following Geological Survey offices:

- ROLLA, Missouri--1400 Independence Rd.

- DENVER, Colorado--Map Distribution, Bldg. 810, Federal Center

- FAIRBANKS, Alaska--New Federal Bldg., 101 Twelfth Ave. 


\section{Depositional Environments for Strata of Composite Section of Frontier Formation, Madison Range, Southwestern Montana}

By R.G. TYSDAL

U.S. GEOLOGICAL SURVEY BULLETIN 1949 


\title{
U.S. DEPARTMENT OF THE INTERIOR
}

\author{
MANUEL LUJAN, JR., Secretary
}

\author{
U.S. GEOLOGICAL SURVEY \\ Dallas L. Peck, Director
}

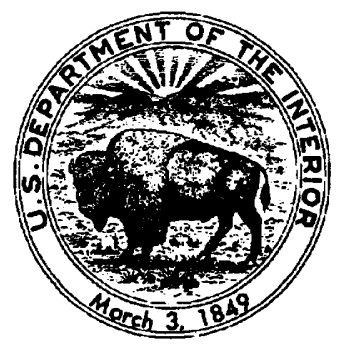

Any use of trade, product, or firm names in this publication is for descriptive purposes only and does not imply endorsement by the U.S. Government.

For sale by the

Books and Open-File Reports Section

U.S. Geological Survey

Federal Center

Box 25425

Denver, CO 80225

\section{Library of Congress Cataloging-in-Publication Data}

Tysdal, Russell G.

Depositional environments for strata of composite section of Frontier Formation, Madison Range, southwestern Montana / by R.G. Tysdal.

p. cm. - (U.S. Geological Survey bulletin ; 1949)

Includes bibliographical references (p. ).

Supt. of Docs. no.: I 19.3:1949

1. Geology, Stratigraphic-Cretaceous. 2. Geology-Montana-Madison

Range. 3. Frontier Formation. I. Title. II. Series.

QE75.B9 no. 1949

[QE685]

$557.3 \mathrm{~s}-\mathrm{dc} 20$

[551.7'7'09786]

90-19939 


\section{CONTENTS}

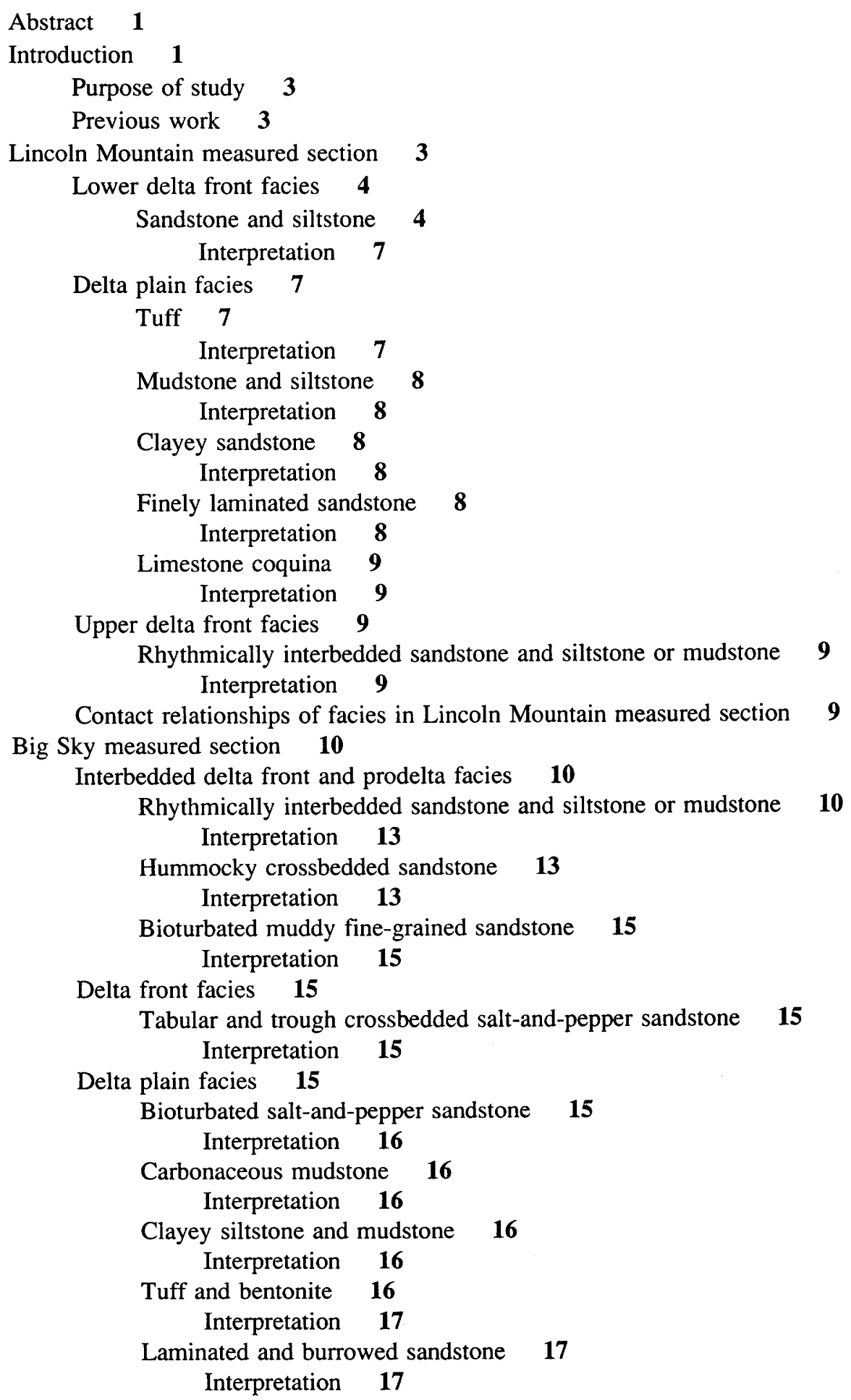




\section{Claystone $\quad 18$ \\ Interpretation 18}

Conglomerate, sandstone, and lenticular-bedded siltstone $\quad \mathbf{1 8}$ Interpretation 20

Contact relationships of facies in Big Sky measured section 20

Conclusions 20

References cited $\mathbf{2 1}$

\section{FIGURES}

1. Map of southwestern Montana showing geographic features and location of measured sections of the Frontier Formation in the Madison Range 2

2. Sequence of Cretaceous formations directly above and below Frontier Formation in Madison Range 2

3. Generalized graphic measured section of lower part of composite section of Frontier Formation, measured at Lincoln Mountain 4

4. Generalized graphic measured section of upper part of composite section of Frontier Formation, measured near Big Sky 5

5. Schematic diagram of delta showing environments interpreted from strata of composite measured section 6

6. Classification of sedimentary environments 7

7-11. Photographs showing:

7. Rhythmically interbedded strata overlain and underlain by hummocky cross-laminated sandstone $\mathbf{1 1}$

8. Rhythmically interbedded sandstone, siltstone, and mudstone $\mathbf{1 1}$

9. Thick sandstone beds in rhythmically interbedded strata 12

10. Ball-and-pillow structure in rhythmically interbedded strata $\mathbf{1 2}$

11. Hummocky cross-laminated sandstone 14

12. Sequence of sedimentary structures in hummocky crossbedded strata

13-14. Photographs showing:

13. Ball-and-pillow structure in tuff bed of delta plain strata 17

14. Tidal channel sandstone and mudstone in upper part of delta plain strata

19 


\title{
Depositional Environments for Strata of Composite Section of Frontier Formation, Madison Range, Southwestern Montana
}

\author{
By R.G. Tysdal
}

\section{ABSTRACT}

The Frontier Formation was measured in two partial sections in the Madison Range in order to obtain nearly complete exposures for stratigraphic and sedimentologic interpretation. The two sections form a composite section for the Frontier. The lower section of the Frontier, measured at Lincoln Mountain where it is $102 \mathrm{~m}$ (336 ft) thick, is a tripartite succession. The lower part consists mainly of sandstone and bioturbated sandstone deposited in a lower shoreface environment of a delta front facies. These strata are conformable with the underlying Mowry Shale. The middle part is composed of thin interbedded strata laid down in a delta plain setting. Tuff of the middle part forms a marker unit of resistant outcrops and likely was deposited subaerially. Carbonaceous mudstone forms marsh deposits that grade into sandstone interpreted as deposits of a sandflat marginal to a lagoon or bay. At one horizon in the middle part, a gently dipping, planar sandstone that contains a few percent of well-rounded quartz grains crops out and is interpreted as an overwash-fan deposit. Limestone coquina composed of brackish-water bivalves caps the middle part and is interpreted as a deposit of a bay or lagoon. The upper part of the sequence present at Lincoln Mountain is composed of rhythmically interbedded mudstone, silty mudstone, and sandstone deposited in a delta front environment, possibly a mouth-bar deposit. An unconformity, which represents much of the Cenomanian as well as early Turonian time, exists between the delta front deposits and those of the underlying delta plain.

The upper section of the Frontier was measured near the

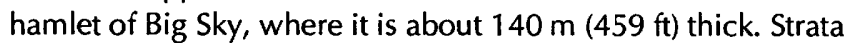
deposited in interbedded prodelta and delta front facies make up most of the section. Delta front clastic rocks include several units of hummocky cross-stratified sandstone, some of which contain abundant trace fossils, and are interpreted as storm deposits. Thinly interbedded siltstone, fine-grained sandstone, and mudstone are interpreted as deposits of a prodelta slope that formed directly seaward of the lower shoreface of a delta

Manuscript approved for publication, June 26, 1990. front. Some of the individual sandstone beds within the prodelta strata show hummocky crossbeds, interpreted as single-event distal storm deposits. Delta front sandstones of the foreshore and backshore record upward shallowing environments.

A delta plain facies forms the upper $25 \mathrm{~m}(82 \mathrm{ft})$ of the measured section near Big Sky. The strata consist of carbonaceous to coaly mudstone, siltstone and claystone, and tuff. These rocks include abundant fresh and brackish water megafossils and sedimentary structures indicative of delta plain lakes and brackish water swamps. The tuffs range from well indurated, silicified beds to deeply weathered bentonitic strata. Some of the tuffs were deposited within water, showing ball-and-pillow structures, whereas other beds may have been deposited subaerially. Uppermost strata of the delta plain sequence constitute an estuarine tidal channel deposit that consists, in ascending order, of pebble conglomerate, finegrained sandstone that contains siltstone to mudstone interbeds, and lenticular bedded mudstone and clayey siltstone. These strata are erosionally based in a mudstone interpreted as a marsh deposit. An unconformity marks the contact of the Frontier Formation with the overlying Cody Shale.

\section{INTRODUCTION}

The Madison Range lies in the Rocky Mountain foreland of southwestern Montana (fig. 1) and contains as much as $4,600 \mathrm{~m}(15,000 \mathrm{ft})$ of Phanerozoic sedimentary strata, which overlie Archean metamorphic rocks. Geologic studies in the Madison Range were undertaken during evaluation of much of the range for inclusion in the National Wilderness System. An understanding of the Cretaceous strata was a prerequisite to deciphering structural features of the range. Detailed measurement of Cretaceous sections permitted correlation of formations throughout the map area. Study of the Frontier Formation led to recognition ofdepositional changes, time constraints, and, ultimately, depositional environments of the strata. 
Cretaceous rocks, virtually all clastic rocks, make up about half of the Phanerozoic sequence in the Madison Range (fig. 2). Sediments of the Frontier were derived from terrane undergoing folding and thrusting in the Sevier orogenic belt in the hinterland to the west. These sediments were deposited in the western part of the Western Interior Seaway in a deltaic setting, which existed in the region of the Madison Range (McGookey and others, 1972).

The Frontier Formation in the Madison Range generally is poorly exposed, and nowhere is the formation exposed in one continuous sequence. The formation is about $217 \mathrm{~m}(713 \mathrm{ft})$ thick in the composite measured section presented here. The lower part of the composite section is exposed at Lincoln Mountain, about $8 \mathrm{~km}(5 \mathrm{mi})$ west of Montana State Highway 191 (fig. 1). The upper part of the composite section is exposed in a lengthy roadcut about 3 $\mathrm{km}(2 \mathrm{mi})$ west of the village of Big Sky. Exposures

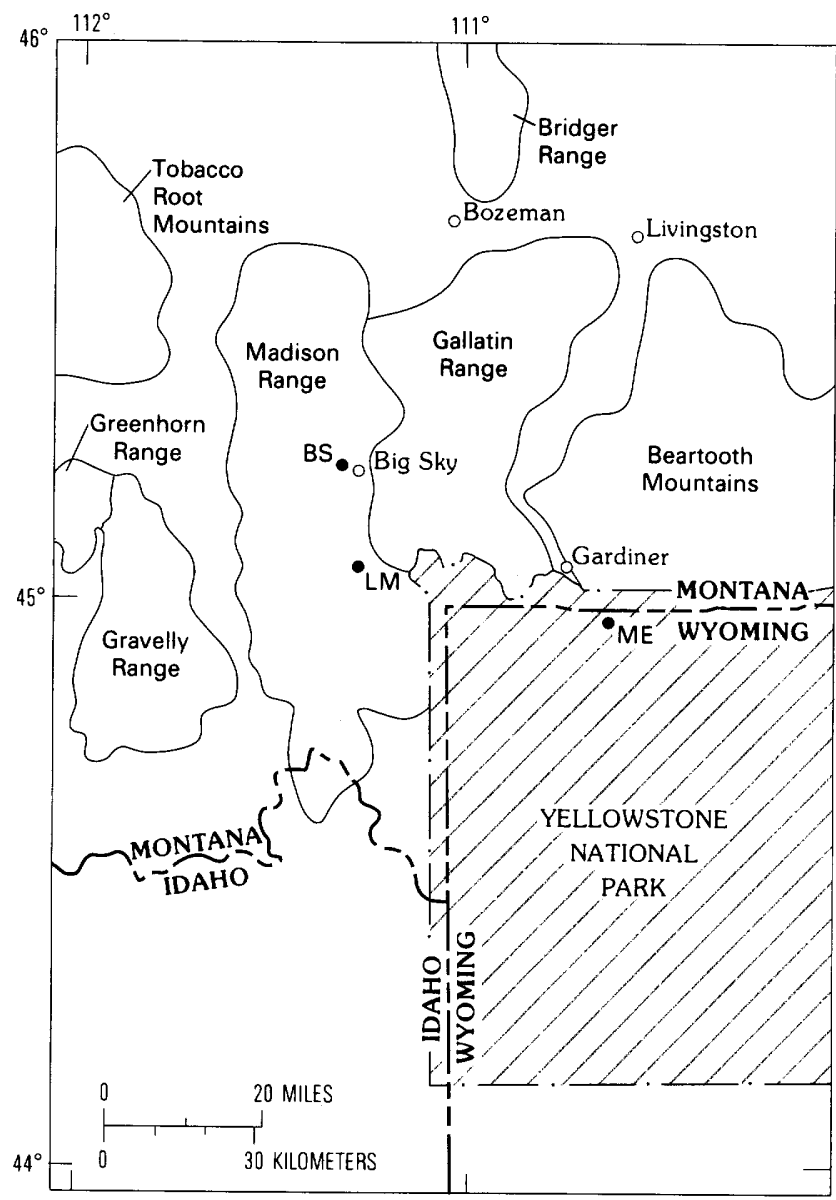

Figure 1. Index map of southwestern Montana showing mountain ranges and locations of measured sections referred to in text. Abbreviations for locations are as follows: LM, Lincoln Mountain; BS, Big Sky; ME, Mount Everts. The Lincoln Mountain locality is site of measured section shown in figure 3, and the Big Sky locality is site of measured section shown in figure 4 .

\begin{tabular}{|c|c|l|}
\hline SYSTEM & SERIES & \multicolumn{1}{c|}{ FORMATION } \\
\hline CRETACEOUS & Upper & $\begin{array}{l}\text { Telegraph Creek Formation } \\
\text { Cody Shale } \\
\text { Frontier Formation } \\
\text { Mowry Shale } \\
\text { Muddy Sandstone } \\
\text { Thermopolis Shale } \\
\text { Kootenai Formation }\end{array}$ \\
\cline { 2 - 3 } & Lower & \begin{tabular}{l} 
Koot \\
\hline
\end{tabular} \\
\hline
\end{tabular}

Figure 2. Sequence of Cretaceous formations present directly above and below Frontier Formation in the Madison Range. Queried boundary of Lower and Upper Cretaceous rocks is based on work of Cobban and Kennedy (1989).

showing the contact of the two parts of the composite section were not found during mapping in the range.

The two measured sections are interpreted as comprising a composite section of the Frontier on the basis of their megafaunal content (Tysdal and others, 1990). Megafossils from the top of the Lincoln Mountain section are of the early middle Turonian Collignoniceras woollgari faunal zone. Megafossils obtained from near the middle of the Big Sky section are fragmented and not abundant, but they are interpreted to represent the late middle Turonian Prionocyclus hyatti faunal zone (W.A. Cobban, in Tysdal and others, 1990). W.A. Cobban (oral commun., 1989) said a possibility exists that the faunal remains could be of forms that are from the older $C$. woollgari zone, but this is not the favored interpretation. If the latter possibility is true, then the two sections could contain some time-equivalent strata, except for uppermost strata of the Big Sky section from which fossils of the $P$. hyatti zone were obtained. The sedimentological interpretations presented here would still pertain, but the lateral relationships of any time-equivalent strata, which would be of different depositional environments, are unknown. The two sections do not share a key bed or like sequences.

Many of the data for this report were obtained from the two measured sections that are graphically displayed in figures 3 and 4. Environments represented in the composite measured section are interpreted within a deltaic framework present in the region at the time of deposition, even though the composite section by itself does not permit the reconstruction of the lateral relationships over long distances. Figure 5 shows a schematic deltaic setting illustrating the depositional enviroments used for interpretation of the strata present in the composite measured section.

The graphic measured sections of figures 3 and 4 were generated from the Stratigraphic Report Graphic, a stratigraphic applications computer program developed by the U.S. Geological Survey and Petroleum Information Corporation of Denver, Colo. (Petroleum Information Corporation, 1984; Dyman and others, 1985). The program 
is proprietary to Petroleum Information Corporation, but it is available by contract to the U.S. Geological Survey for a variety of research applications.

Megafossils discussed in this report were identified by W.A. Cobban and, except where specifically noted, their names were published previously in Tysdal and others (1990).

\section{Purpose of Study}

The Frontier Formation in the Madison Range affords a key composite measured section for regional stratigraphic correlation. The Madison Range composite section is about $80 \mathrm{~km}(50 \mathrm{mi})$ southwest of outcrops near Livingston, Mont.; $55 \mathrm{~km}(35 \mathrm{mi})$ west of outcrops at Mount Everts in the northernmost part of Yellowstone National Park; and $200 \mathrm{~km}(125 \mathrm{mi})$ northwest of outcrops in the Jackson Hole area of northwestern Wyoming, south of the Park (fig. 1). Frontier strata have been eroded from most of the region between the Madison Range and these other areas, although, locally, Frontier strata are concealed beneath younger sedimentary and volcanic rocks. Strata of the Big Sky measured section are younger than those of sections in some areas to the east, facies differ from some of those present in other areas, and the strata are distant from those of other areas. Frontier strata in the Greenhorn Range, about $55 \mathrm{~km}$ (35 mi) west of the Madison Range, are much thicker and were deposited in marginal marine and nonmarine environments (Tysdal and others, 1990). The purpose of this report is to describe the strata of the composite measured section and to interpret their depositional environments.

In this report, "lithologic unit" is used as a nongenetic term to describe a specific kind of rock (for example, sandstone, limestone, tuff); or to describe interbedded rocks of different kinds (for example, interbedded sandstone and mudstone) that, combined, form a distinct rock unit. The term has virtually the same meaning as the informal lithostratigraphic unit called a lithosome (Bates and Jackson, 1987, p. 384), which has fallen into disuse in recent years. The Lincoln Mountain section (fig. 3) and the Big Sky section (fig. 4) each is composed of lithologic units that are numbered sequentially from bottom to top. Depositional environments are interpreted for each of the lithologic units, which are placed within a deltaic framework facies (for example, delta plain facies) as shown in figure 6. Contact relationships for the facies are discussed for each of the measured sections.

\section{Previous Work}

The Frontier Formation in the Madison Range was first distinguished from other Cretaceous strata by Tysdal and Simons (1985) during mapping in the central and southern part of the range. The lower contact of the Frontier was placed at the base of the first sandstone unit above dark-gray mudstone and silty mudstone assigned to the Mowry Shale (Tysdal and others, 1989a, b). A graphic composite section and description of rock units that make up the formation were presented in Tysdal and others (1990).

Many studies in the Madison Range were mapping projects in which Frontier strata were not distinguished from most other Cretaceous rocks. Frontier strata are part of a unit mapped as "Colorado and Montana formations" (Peale, 1896), Colorado Group (Becraft and others, 1970; Garihan and others, 1983), and an unnamed unit (Swanson, 1950). Along the western flank of the central part of the Madison Range, Hadley $(1969,1980)$ used the name Frontier Formation for a thick succession of strata that included the Frontier Formation as used here, but also he included several formations that underlie and overlie the Frontier. In the east-central part of the Madison Range, much of the previous work constituted fairly detailed thesis studies. Hall (1961), Lauer (1967), Ray (1967), Rose (1967), Bolm (1969), Kehew (1971), and Walsh (1971) used Cretaceous strata undivided or undifferentiated for rocks that included part or all of the Frontier Formation.

Some of the lower Frontier strata at Lincoln Mountain were assigned to the Mowry Shale by Wilson (1970) and Vuke (1982, 1984). Schwartz (1972) assigned the same lower Frontier strata to his Blackleaf Formation unit D, which he equated with the Mowry. Austin and Stoever (1950) assigned the same Frontier strata to the Aspen(?) Formation, a name used in western Wyoming and eastern Idaho. These assignments of lower Frontier strata to other formations were made, at least in part, to include porcellanitic tuff (fig. 3, lithologic units 13,14) that lies about $33 \mathrm{~m}$ (108 ft) above the base of the Frontier as mapped by Tysdal and Simons (1985) and Tysdal (1990) and as defined in some detail by Tysdal and others (1989a, b; 1990). Pastelcolored porcellanitic and bentonitic strata are common in the lower part of the Mowry Shale, $84 \mathrm{~m} \mathrm{(274} \mathrm{ft)} \mathrm{beneath}$ the base of the Frontier at Lincoln Mountain. The above thesis authors probably thought that the porcellanitic tuff of units 13 and 14 of the Frontier represented additional volcanic material of the Mowry. The pastel strata were assigned to the Vaughn Member of the Mowry Shale by Tysdal and others (1989b).

\section{LINCOLN MOUNTAIN MEASURED SECTION}

Delta front and delta plain facies are represented in strata that make up the section of the lower part of the Frontier measured at Lincoln Mountain. The strata are 
EXPLANATION

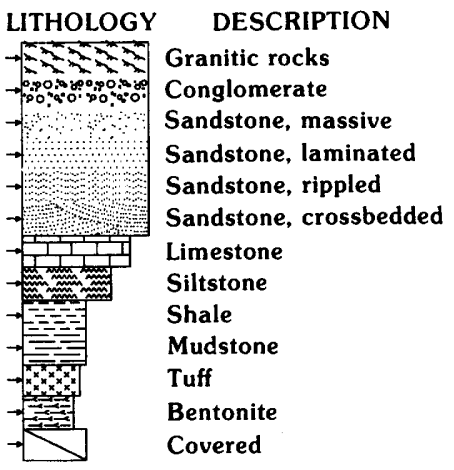

Figure 3. Graphic log of lower part of Frontier Formation, showing facies interpreted for sequences of lithologic units. Arrow to right of each lithologic unit number points to middle of unit. The section was measured in gently dipping strata on Lincoln Mountain, NW $1 / 4$ NW $1 / 4$ sec. 7 , T. 9 S., R. 4 E., Lincoln Mountain 7.5-minute quadrangle.

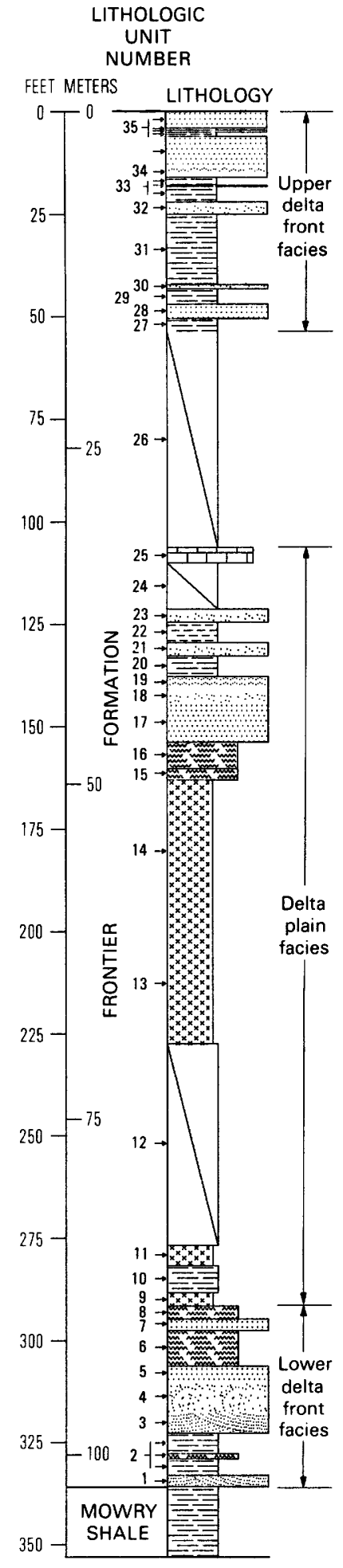

UNIT transitional with the underlying Mowry Shale, but the top of the uppermost strata of the section is a present-day erosional surface. The lithologic unit numbers referenced in the text concerning the measured section at Lincoln Mountain correspond to those in figure 3 and to the those presented in Tysdal and others (1990).

\section{Lower Delta Front Facies}

\section{Sandstone and Siltstone}

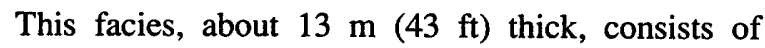
interbedded sandstone and lesser siltstone and mudstone 


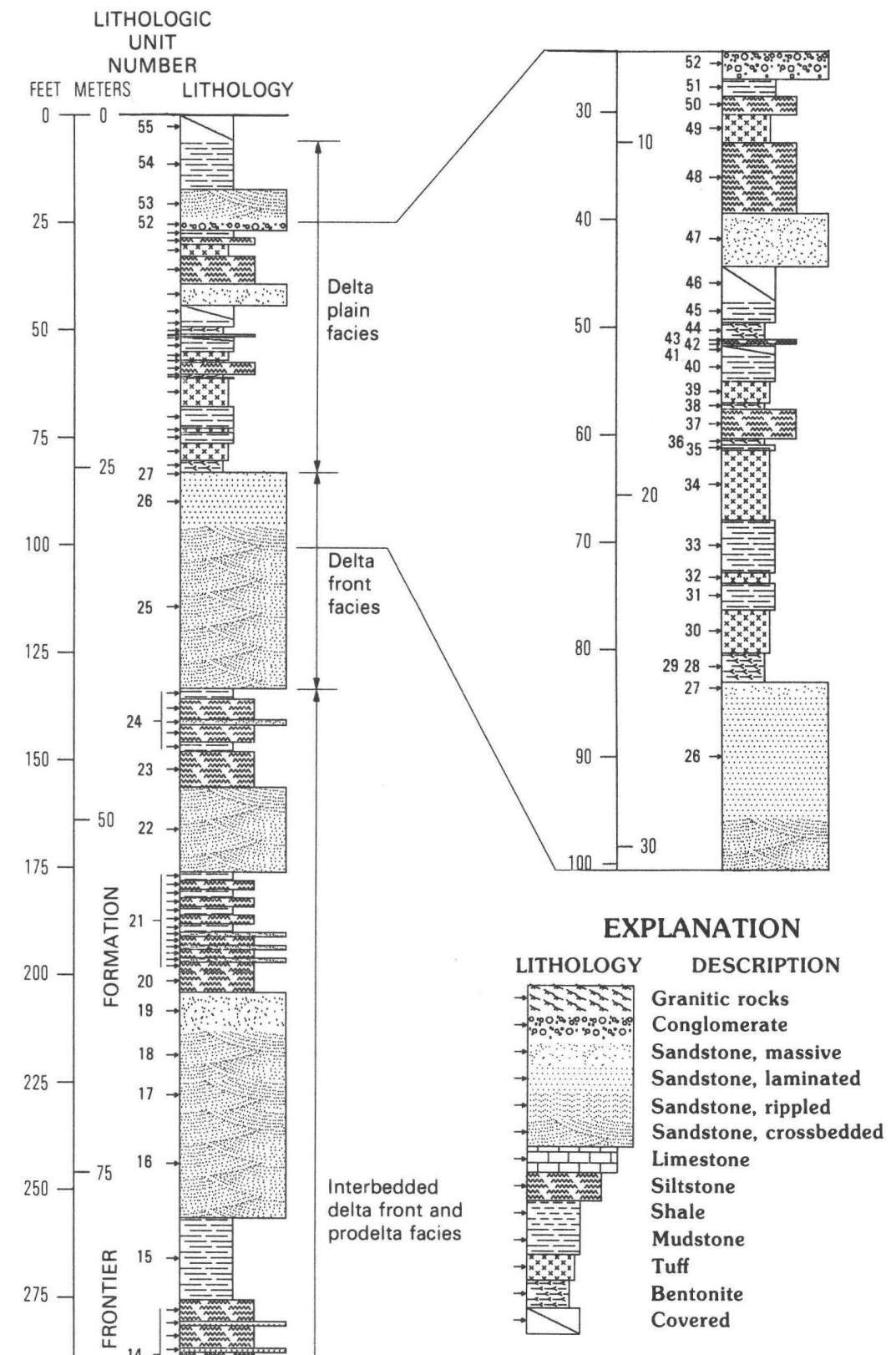

Figure 4. Graphic log of upper part of Frontier Formation, showing facies interpreted for sequences of lithologic units. Arrow to right of each lithologic unit number points to middle of unit. The section was measured in gently dipping strata $3.7-5.6 \mathrm{~km}(2.3-3.5$ mi) west of the Post Office in the village of Big Sky, Mont., in roadcuts in the SE $1 / 4$ sec. 28 and SW $1 / 4 \mathrm{SW}^{1 / 4}$ sec. 27, T. 6 S., R. 3 E., thence southeastward from the road along the ridge crest in the NW $1 / 4$ sec. $34, T$. 7 S., R. 3 E., Gallatin Peak 7.5-minute quadrangle. 


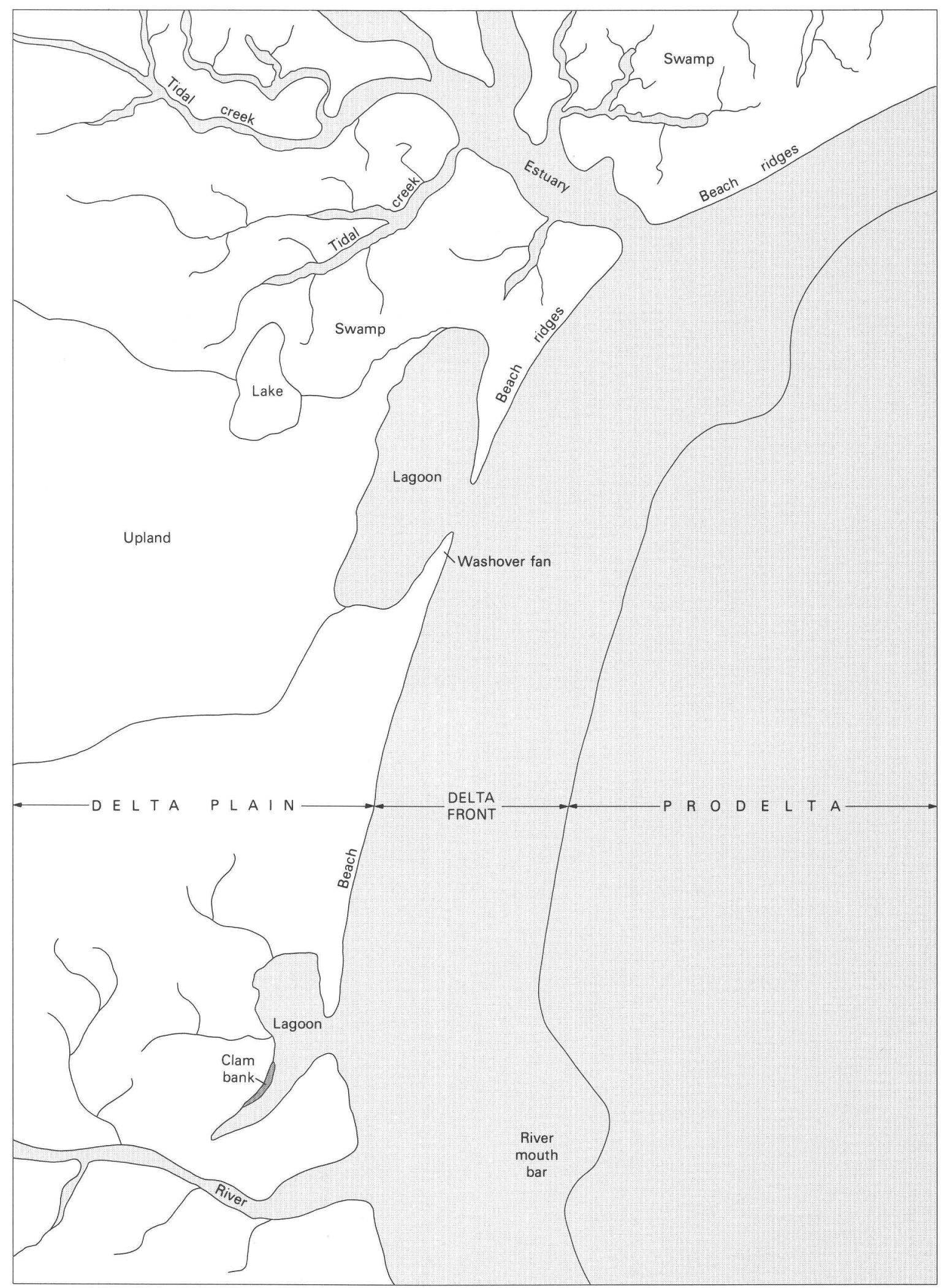

Figure 5. Schematic diagram of a delta showing depositional environments that are interpreted to be represented by strata in the composite measured section of the Frontier Formation in the Madison Range. 


\begin{tabular}{|l|l|}
\hline $\begin{array}{l}\text { DEPOSITIONAL } \\
\text { ENVIRONMENT }\end{array}$ & FACIES \\
\hline $\begin{array}{l}\text { Lake or pond } \\
\text { Lagoon } \\
\text { Backshore } \\
\text { Dune }\end{array}$ & Delta Plain \\
\hline $\begin{array}{l}\text { Foreshore } \\
\text { Upper shoreface } \\
\text { Lower shoreface }\end{array}$ & Delta Front \\
\hline Offshore & Prodelta \\
\hline
\end{tabular}

Figure 6. Diagram showing the facies classification scheme used in this report and the corresponding depositional environments interpreted for strata of the Frontier Formation in the Madison Range.

(lithologic units 1-8). The units are generally $1-2 \mathrm{~m}(3-7 \mathrm{ft})$ thick and record an abrupt change in grain size from the mudstone and clayey siltstone that characterize the underlying Mowry Shale. The sandstone is greenish gray and is composed of quartz, feldspar, chert, rock fragments, mica, and locally glauconite. Sorting ranges from good to poor, with some strata (fig. 3, lithologic units 4, 5, and 7) consisting of grains that range from very fine to fine and, locally, medium size, along with clay. Beds are commonly thin, planar, and finely laminated. Sandstone of units 1 and 3 is thin to medium bedded and displays both plane beds and low-angle crossbeds. Dark-brown to gray carbonaceous mudstone and clayey siltstone, like that in the upper part of the underlying Mowry Shale, occur locally (unit 2) in the lower part of the sequence. Siltstone and clayey siltstone units are thinly bedded and finely laminated to rippled.

Ophiomorpha burrows are abundant in lithologic unit 5 and so are fragments of megafossils and plants. Bioturbation has disrupted most of the laminae of units 4,5 , and 7. The following megafossils, which are not age-diagnostic, were collected from unit 1 by Tysdal and others (1990): Oxytoma sp., Camptonectes sp., Aphrodina sp., Goniomya sp., Lingula subspatulata Hall and Meek, a juvenile ammonite of indeterminate species, and fish bones. Unit 6 yielded a palynomorph assemblage of mixed marine and nonmarine fossils (Tysdal and others, 1990). This palynomorph assemblage, and those from the underlying Mowry Shale that were previously assigned to the Albian by Tysdal and others $(1989 a, b)$, are considered to be early Cenomanian in age. The early Cenomanian age is based on a reinterpretation of molluscan megafossil data of the Cretaceous Western Interior (Cobban and Kennedy, 1989); assignments for palynomorphs assemblages are based on correlation with the Cretaceous molluscan fossil zones.

\section{Interpretation}

Lithologic units 1-8 form a sequence deposited in shallower water than that of the mudstone and clayey siltstone in the underlying Mowry Shale. Intertonguing of lithic units of differing grain size reveals a gradual upward increase in grain size from underlying Mowry strata and reflects a gradual overall increase in wave energy. The sequence displays physical sedimentological features characteristic of lower shoreface deposits, as described by Reinson (1984) and Leckie and Walker (1982). The lower shoreface is a low energy environment where waves first begin to affect bottom sediments. Sands are generally fine to very fine grained and contain interlayered silt and clay. Laminae are planar but commonly are obliterated by bioturbation. The abundant fossil fragments of differing sizes indicates little reworking by waves.

Megafossils present in the lowermost unit are marine forms. The palynomorphs of unit 6 are a mixed assemblage of marine and nonmarine forms. This grouping of mixed forms is most likely to occur in a nearshore marine setting where nonmarine palynomorphs constitute an admixture, assuming the marine fossils are not recycled. The horizontal boxwork pattern displayed by Ophiomorpha (lithologic unit 5)-the burrow of a suspension-feeding animal-also is characteristic of the lower shoreface. Ophiomorpha has two general patterns of occurrence: steeply inclined shafts, which predominate in higher energy environments (such as the upper shoreface or foreshore), and boxwork mazes, which characterize lower energy environments (such as the lower shoreface) (Frey and others, 1978).

\section{Delta Plain Facies}

This facies totals about $56 \mathrm{~m}(184 \mathrm{ft})$ thick and contains thin interbedded lithologic units deposited in several closely related depositional environments of a delta plain.

\section{Tuff}

Pale-yellowish-green to medium-gray indurated tuff (fig. 3, lithologic units 9,11,13, and 14) forms prominent outcrops in the middle part of the Lincoln Mountain section. Units 13 and 14 together form a marker unit that is about 20 $\mathrm{m}(66 \mathrm{ft})$ thick at Lincoln Mountain and is widespread in the central part of the Madison Range. The tuff is glassy (porcellanitic) and breaks with a conchoidal fracture. It is well indurated, although not welded, and contains well preserved shards and some nearly complete bubble structures. Plagioclase phenocrysts are widely dispersed within the tuff; biotite is a minor constituent. None of the phenocrysts or shards, some of which are elongate, show preferred orientation.

\section{Interpretation}

Tuffs of units 13 and 14 are interpreted as airfall deposits laid down subaerially on a delta plain. The lack of preferred orientation of the constituents of the tuff, and 
preservation of delicate elongate shards and nearly complete bubbles within glass, indicate that the constitutents did not undergo sorting by water. The tuffs of units 9 and 11 were not examined in thin section; thus, their internal fabric is unknown, and it is uncertain if the tuffs were deposited subaerially or in water. None of the units show balland-pillow structures, which would indicate deposition on a muddy, water-saturated substrate.

\section{Mudstone and Siltstone}

Dark-gray to olive-brown mudstone, clayey siltstone, and shale make up most of the strata of lithologic units 10 , $15,16,20$, and 22 (fig. 3). Thin interbeds of bentonite are present in units 10,15 , and 16. Each of the five units is $1-2$ $\mathrm{m}(3-7 \mathrm{ft})$ thick and is poorly exposed. The rocks contain comminuted carbonaceous debris and generally lack sedimentary structures that are visible in the outcrop or hand specimens. Clayey siltstones contain thin interbeds of finely laminated bentonite (weathered tuff). Unit 16 contains a freshwater gastropod, Carinorbis sp., and upper units are closely associated with strata that contain brackish water fossils (see next section), but no fossils were recovered from these other units.

\section{Interpretation}

The mudstones and clayey siltstones were laid down where nonmarine and brackish water environments merge and are interpreted as deposits of the lower part of a marsh that fringed a restricted bay or a lagoon. The interlayered bentonites of units 10,15 , and 16 are subaerial tuffs, and unit 16 contains a nonmarine fauna. The upper two lithologic units (20 and 22) of the lithofacies are interbedded with strata that contain a brackish water fauna and are thought to be deposits of a restricted bay. The siltstone of unit 16 is thoroughly burrowed. Preservation of the fine layers of bentonite in some of the lower rock units at Lincoln Mountain suggests a quiet depositional environment that lacked reworking by burrowing organisms or plants. This lack of reworking could indicate deposition in an anoxic environment, such as a pond, or perhaps deposition of the volcanic ash caused temporarily unfavorable living conditions for infauna.

\section{Clayey Sandstone}

Sandstone strata included here range from clay-rich to clay-poor and are 1-1.5 m (3-5 ft) thick. Lithologic unit 23 (fig. 3) is a clay-rich sandstone that is dark gray, fine grained, clayey, carbonaceous, and rubbly weathering. Clay-poor sandstone units 18 and 21 are medium and light gray, fine to medium grained, and chert- and quartz-rich. A

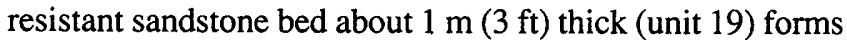
the most distinctive lithologic unit and includes both clayey and fairly "clean" sand. Most of the bed is very dark gray to black sandstone that has a matrix of carbonaceous mudstone. The dark sandstone contains abundant brackish water fossils in a near-coquinoid assemblage of Veloritina? sp., a gastropod; and Corbula, aff. C. subtrigonalis Meek and Hayden, and Melania sp., which are bivalves. The mediumto light-gray sandstone of the upper few centimeters of unit 19 is slightly calcareous and displays planar to wavy laminations. No megafossils were found in the upper part of unit 19 , but nearly vertical burrows of the trace fossil Skolithos are present. The animal that produced the trace fossil Diplocraterion caused mixing of clay into the sandstone.

\section{Interpretation}

The fairly clean sandstones of units 18,21 , and the upper few centimeters of unit 19 are interpreted as intertidal deposits laid down in the foreshore to shoreface of a lagoon or a bay. Sandstones with a claystone matrix of high organic content (carbonaceous) (unit 23 and lower part of unit 19) and the brackish water faunal assemblage of unit 19 both are suggestive of the shallow part of a lagoon or bay, similar to modern lagoons described, for example, by Shepard and Moore (1955), Newman and Munsart (1968), and Warme (1971). The change in composition from a mixed sandstone and mudstone in the lower part of unit 19 to a fairly clean sandstone with vertically oriented trace fossils in the upper part indicates a change in energy conditions. The lower part represents quiet water deposition relative to the upper part that likely was directly affected by waves and (or) currents. The change is abrupt and is consistent with a change from subtidal or lower intertidal to intertidal shoreline (sandflat) deposit of a lagoon or bay. The sandy fossil-bearing strata also could have been deposited in a tidal channel that coursed its way through intertidal deposits (Howard and Frey, 1975; Thorbjarnarson and others, 1985), although this seems less likely.

\section{Finely Laminated Sandstone}

Finely laminated sandstone of lithologic unit 17 (fig. 3 ) is about $10 \mathrm{~m}(33 \mathrm{ft})$ thick and is composed of light-greenish-gray sandstone that is fine grained and poorly sorted. Beds are $1-3 \mathrm{~cm}$ thick, dip 1-2 , are planar and finely laminated. The sandstone is composed of quartz, chert, feldspar, rock fragments, and glass shards. Some of the quartz grains are well rounded.

\section{Interpretation}

The strata are interpreted as a storm washover-fan deposit on the basis of bedding style, primary sedimentary structures, composition, and stratigraphic position. Thin, flat beds that commonly dip $1-4^{\circ}$ toward a fan terminus are 
the dominant bedding style of washover fans (Hayes, 1967; Schwartz, 1981; Barwis and Hayes, 1985). The strata lie within a regressive sequence. Because washover fans occur at high elevations in a barrier sequence, their preservation potential is greatest in a regressive succession where they can be buried beneath prograding back-barrier sediments. Strata associated with unit 17 are nonmarine, downsection a few meters, and a bay or lagoonal sandstone containing brackish-water fossils a few meters upsection. Lateral exposures are not sufficient to observe intertonguing of the different stratigraphic units.

\section{Limestone Coquina}

The delta plain facies is capped by a prominent bed (fig. 3, lithologic unit 25) of light-gray limestone coquina composed of the brackish water mollusks Leptesthes sp., Veloritina sp., and Corbula sp. in a matrix of micrite. Disarticulated bivalves of the nonmarine mollusk Protoelliptio hamili (McLearn) were reported by Wilson (1970) from this unit. Residue of the limestone contains abundant charophytes (W.A. Bryant, USGS, oral commun., 1988).

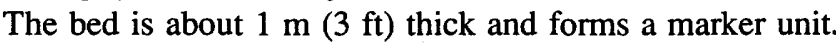

\section{Interpretation}

The coquina of unit 25 is interpreted as a brackishwater limestone deposited along the margin of a restricted bay or perhaps along a tidal stream. Charophytes, green algae of which modern species reside only in nonmarine habitats, mixed with the brackish-water mollusks, indicate that fresh water carried materials to the depositional site. The fossils have been reworked into an assemblage of fragmented debris by wave or current action. Brackishwater assemblages of fragmented megafossils are common in the back-barrier bays of the Mississippi delta, where they are concentrated by storm processes (Kosters, 1989).

\section{Upper Delta Front Facies}

\section{Rhythmically Interbedded Sandstone and Siltstone or Mudstone}

Strata of this facies (fig. 3, lithologic units 27-35) consist of rhythmically interbedded sandstone and mudstone about $16 \mathrm{~m}(52 \mathrm{ft})$ thick. (The 16-m- (52-ft-) thick covered interval of unit 26 is not assigned to a facies.) The overall sequence coarsens upward, however. Mudstone comprises a greater volume of strata of the lower part of the sequence composed of units 27-35 and sandstone the greater volume of the upper part. Mudstone ranges from light gray to dark olive gray, is carbonaceous, thin bedded, and finely laminated. The mudstone is sandy locally, but in the lower part of the sequence some strata are fissile, micaceous, and shaly.

Sandstone ranges from olive-green to gray-green or gray-brown and is composed of quartz, chert, feldspar, and minor glauconite. The grain size commonly is fine to medium, although lithologic unit 35 locally is coarse grained and contains well-rounded chert pebbles in layers as much as $5 \mathrm{~cm}$ ( 2 in.) thick. Most beds are only a few centimeters thick and show planar lamination, but a few beds in the upper part are as much as $50 \mathrm{~cm}$ (20 in.) thick. Some sandstone beds are lenticular, others are sharp-based and eroded into underlying sandstone to form composite or amalgamated beds. The $1-\mathrm{m}-(3 \mathrm{ft})$ thick sandstone of unit 28 , in the basal part of the sequence, grades from massive in the lower part; through plane-bedded in the middle; to finely laminated, wavy cross-laminated paper-thin layers in the upper part. Tool marks (flute and groove casts), oscillatory ripple marks, and horizontal burrows indicative of the Cruizana ichnofacies are common on bedding planes of sandstone in the upper third of the sequence of units 27-35.

The only fossils recovered from units 27-35 are of the middle Turonian mollusk Collignoniceras woollgari (Mantell), and some associated fish vertebrae (Tysdal, 1989; Tysdal and others, 1990). The fossils were found on bedding planes of the uppermost sandstone, which also contained tool marks.

\section{Interpretation}

Strata that make up the uppermost part of the Lincoln Mountain section are interpreted as delta-front sandstones, possibly distributary mouth-bar deposits, laid down directly shoreward of a prodelta slope. Rhythmic interbedding of fine-grained sandstone and mudstone or siltstone are typical features for this environment, as are graded sandstone beds (unit 28) (Allen, 1965). Most beds lack the grading displayed by unit 28 , but both the grading and tool marks, displayed on several beds, would be expected in a setting where sediment was deposited rapidly from a turbid plume of river water debouching onto a delta front. Oscillatory ripple marks and trace fossils of the Cruizana ichnofacies both are features common to low wave-energy environments.

\section{Contact Relationships of Facies in Lincoln Mountain Measured Section}

The basal contact of the lower delta front facies of the Frontier Formation at Lincoln Mountain clearly is conformable with strata of the underlying Mowry Shale. Strata of the two formations are gradational, and the change 
in nomenclature was determined on the basis of a fairly abrupt influx in silt and sand content from mudstone of the Mowry to sandstone assigned to the Frontier (Tysdal and others, 1990).

The contact of the lower delta front facies and the overlying delta plain facies is a hiatus, based on faunal content and interpretation of sedimentary environments. The upsection change in facies-from offshore strata in the upper part of Mowry Shale, to delta front strata (lower shoreface environment) of the Frontier, to delta plain strata of the Frontier-is a regressive sequence. Absence of upper shoreface and foreshore strata between the lower Frontier and delta plain sequences suggests that strata of these environments were deposited and later eroded. This could have been accomplished by a drop in sea level and erosion of the upper shoreface and foreshore deposits. Strata of the delta plain would have shifted seaward. With this interpretation, strata of the delta plain facies are closely related genetically and in time to the underlying Frontier and Mowry strata.

The contact of the regressive delta plain facies with the overlying upper delta front facies at Lincoln Mountain is not exposed. However, the marked contrast in depositional environments-brackish-water deposits of the uppermost delta plain facies to marine deposits of the delta front facies-almost certainly requires that a environmental change exist within the 16-m- (52-ft-) thick covered interval (unit 26) between the two facies. Further, the delta front facies is of middle Turonian age, in contrast to the early Cenomanian age of the regressive strata of the underlying part of the Frontier. The major hiatus between the two facies corresponds to the lacuna of the early Cenomanian-middle Turonian unconformity reported by Merewether and Cobban (1986) in western Wyoming and northward into central Montana (near Townsend, fig. 1).

\section{BIG SKY MEASURED SECTION}

Deltaic strata of prodelta, delta front, and delta plain facies crop out in the section of the upper part of the Frontier, measured near Big Sky. A covered interval and a thick granitic sill lie at the base of the section. Rocks beneath the sill, including strata correlatable with the lower section at Lincoln Mountain, are not exposed. The lithologic unit numbers referenced in the text concerning the section measured near Big Sky correspond to those in figure 4 and to those presented in Tysdal and others (1990).

\section{Interbedded Delta Front and Prodelta Facies}

Rocks of the lower part of the delta front and upper part of the prodelta facies form repeated lithologies within a progradational (regressive) marine sequence. The facies is $87 \mathrm{~m}$ (285 ft) thick near Big Sky, making up the major part of the measured section.

\section{Rhythmically Interbedded Sandstone and Siltstone or Mudstone}

This recurring assemblage of rocks (fig. 4, lithologic units $7,9,11,13,14,15,20,21,23$, and 24) consists of rhythmically interbedded siltstone or mudstone and lesser amounts of fine-grained sandstone (figs. 7 and 8). Two thin beds of bentonite (lithologic units 10 and 12) occur within the rhythmically interbedded sequence. The rhythmically interbedded strata are 1-7 m (3-23 ft) thick. Lithologic units $7,9,11$, and 20 contain thin-bedded finely laminated siltstone and mudstone; sandstone is absent. Beds commonly range between $1 \mathrm{~cm}(0.4 \mathrm{in}$.) and about $10 \mathrm{~cm}(4$ in.) thick, but a few are as much as $20 \mathrm{~cm}(8 \mathrm{in}$.) thick (fig. 9). Some of the sandstone fills erosional scours into the underlying siltstone or mudstone, forming sandstone lenses a few centimeters to tens of centimeters across. Pale-colored fine-grained sandstone traced laterally locally intertongues with dark siltstone, such that the sandstone is really a composite or amalgamated bed. Similar relationships were described by Swift and others (1987) in Cretaceous strata of central Utah.

The thickness and abundance of sandstone beds decrease upward; above unit 19 , the lower few meters of these units contain more than 50 percent sandstone. Some sandstone beds only a centimeter or two thick are hummocky cross-stratified, and the clayey siltstone that overlies each sandstone bed reflects this microtopography. In other sandstone beds, hummocks grade laterally and upward into plane-bedded sandstone, which is overlain by siltstone and (or) mudstone. The base of each sandstone bed commonly is sharp, overlying mudstone.

A few groove casts were observed at the base of sandstone beds and graded sandstone beds occur locally. Horizontal burrows were found on a few beds, and vertical burrows occur in hummocky sandstone beds in a few places, but neither type of burrow is common. Chondrites burrows are present locally in mudstones that overlie beds of hummocky cross-laminated strata but also are not common.

Ball-and-pillow structures (fig. 10) form a zone about $50 \mathrm{~cm}(20 \mathrm{in}$.) thick in the lower part of unit 21 of the rhythmically interbedded strata. These ellipsoidal pillowshaped structures formed from a bed of fine-grained sandstone that became segmented and foundered into the underlying silty mudstone. In some cases, the segmentation was not completed and some of the pillows are still connected. The pillows are fairly evenly spaced and range from $20-30 \mathrm{~cm}(8-12$ in.) thick and from $100-125 \mathrm{~cm}$ (39-49 in.) wide; the length of the structures could not be determined. The laminae within each pillow are concave upward, parallel to the outline of the pillow and parallel to 




Figure 7. Rhythmically interbedded sandstone, siltstone, and mudstone of lithologic units 23 and 24 (dark gray) between light-gray hummocky cross-laminated sandstone of lithologic units 22 and 25 . Outcrop is about $25 \mathrm{~m}$ (82 ft) high roadcut in Big Sky measured section, SW $1 / 4 \mathrm{SW}^{1 / 4} \mathrm{sec}$. 27, T. 6 S., R. 3 E., Gallatin Peak 7.5-minute quadrangle.

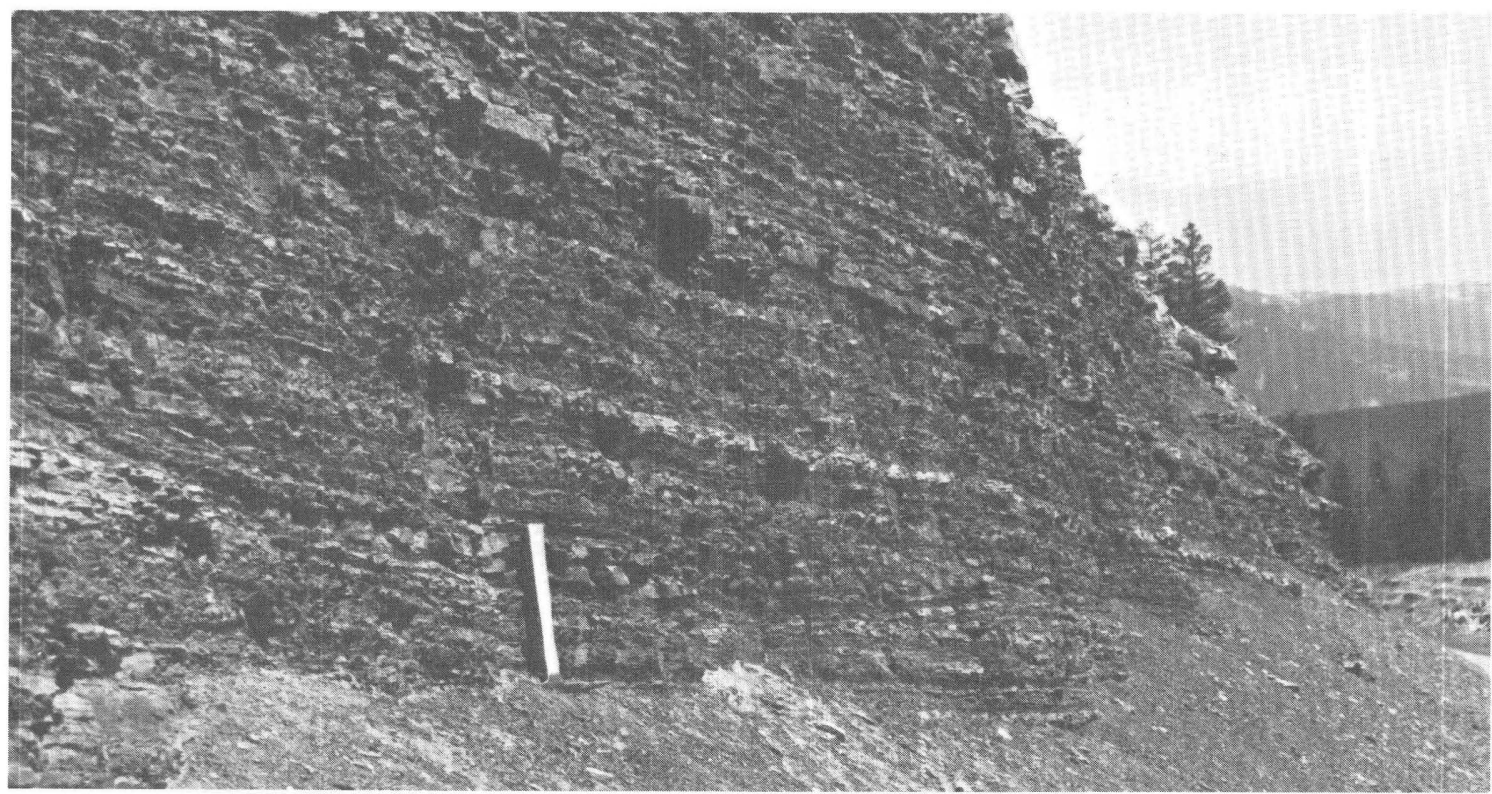

Figure 8. Rhythmically interbedded sandstone, siltstone, and mudstone of lithologic unit 24. Hammer handle is $30 \mathrm{~cm}$ (12 in.) long. Outcrop is in roadcut of Big Sky measured section, SW $1 / 4$ SW $1 / 4$ sec. 27, T. 6 S., R. 3 E., Gallatin Peak 7.5-minute quadrangle.

the flow structure displayed by the surrounding mudstone. The upper part of each pillow has been eroded: nearly vertical laminae in the outer part of each pillow, as well as the vertical flow structure of the mudstone between the pillows, is overlain by undeformed, nearly horizontally bedded silty mudstone or fine-grained sandstone. 




Figure 9. Thick sandstone beds, some of which contain hummocky crossbeds, in rhythmically interbedded strata of

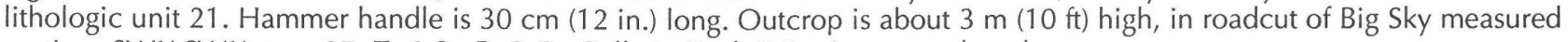
section, SW $1 / 4 \mathrm{SW}^{1 / 4} \mathrm{sec}$. 27, T. 6 S., R. 3 E., Gallatin Peak 7.5-minute quadrangle.

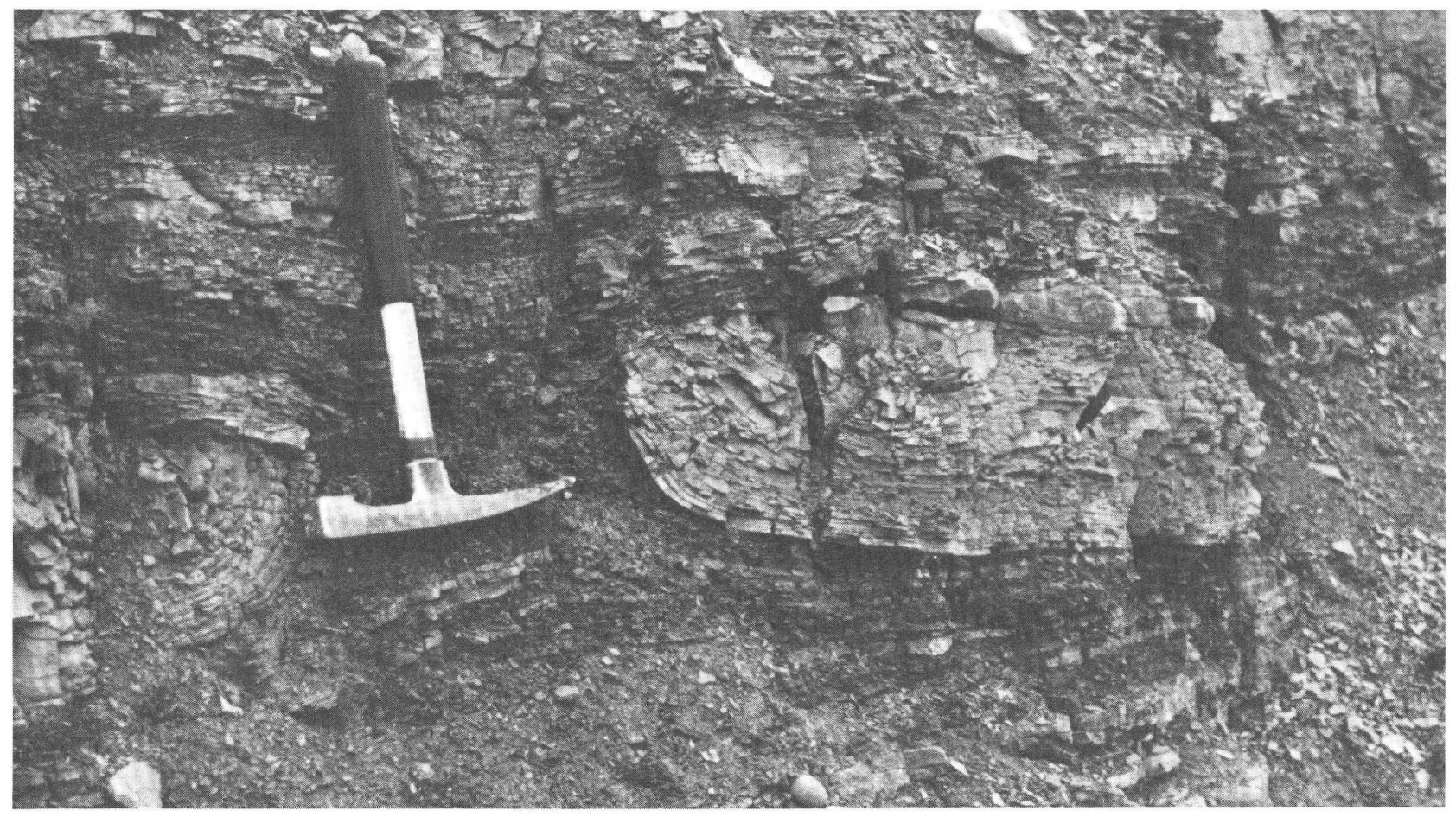

Figure 10. Ball-and-pillow structures in lower part of lithologic unit 21 of rhythmically interbedded strata. Note upturning of sandstone along margins of pillows, opposite both ends of hammer head. Hammer handle is $30 \mathrm{~cm}$ (12 in.) long. Outcrop is in roadcut of Big Sky measured section, SE1/4SE1/4 sec. 27, T. 6 S., R. 3 E., Gallatin Peak 7.5-minute quadrangle. 


\section{Interpretation}

The depositional environment of the rhythmically interbedded sandstone and siltstone or mudstone is interpreted to be a prodelta slope, where it is transitional with the lower shoreface environment of the delta front facies. Hummocky cross-stratification (unit 21) in finegrained sandstone is a storm wave-generated feature; hence, the feature formed above storm wave base but below fair-weather wave base (Harms and others, 1982). The few graded beds and tool marks found may have been produced by storm processes as well.

Ball-and-pillow structures are characteristic of deltafront facies (Howard and Lohrengel, 1969; Hubert and others, 1972). The structures form during soft sediment deformation when a dense sand layer is deposited on top of a less dense, loosely packed water-saturated layer of mud. Gravitational instability causes the less dense watersaturated mud to flow upward, disrupting the sand layer into segments that were deformed into pillow shapes (Allen, 1982, p. 363).

Eroded tops of the ball-and-pillow structures in the Big Sky section indicate that the structures developed shortly after deposition of the sandstone bed from which they formed, and prior to burial beneath the overlying layer of strata. Sandstone of the ball-and-pillow structures was examined for hummocky crossbedding, which would indicate rapid deposition of the sand. Rapid deposition would have facilitated flowage and formation of the balland-pillow structures (Chan and Dott, 1986). No hummocky crossbedding was found, although hummocky sandstone lies directly upsection.

\section{Hummocky Crossbedded Sandstone}

Sandstone beds of several lithologic units (fig. 4, units $2,3,4,5,6,16,17,18,22$, and lower part of unit 25) range from 2 to $8 \mathrm{~m}$ ( 6.5 to $26 \mathrm{ft})$ thick in the measured section of the upper part of the Frontier and all except units 2 and 3 (described and discussed later) show features typical of hummocky cross-stratification as described by Harms and others (1975): (1) crossbed sets display lower bounding surfaces that are erosional, commonly sloping at angles of less than $15^{\circ}$; (2) overlying laminae are parallel to set boundaries, or nearly so; (3) laminae above the erosional base systematically thicken laterally in a set, such that their traces on a vertical surface are fan-like; and (4) the direction of dip of erosional set boundaries are scattered. At Big Sky individual fan-like structures locally can be seen to fill depressions; laminae are nearly parallel to the erosional surface at the base of a crossbed set, gradually fill the erosional scour and decrease in dip until a horizontal dip is attained upward, and then build upward to form a hummock from which the laminae dip outward.

Laminae in the hummocky beds range from less than $1 \mathrm{~mm}$ to $1 \mathrm{~cm}$ (0.04 to 0.4 in.) thick (fig. 11) and are alternately cream colored and pale green. Each light-colored lamina is composed of well-sorted fine-grained quartzofeldspathic sand, mica, and minor clay; each pale-green lamina is composed of clay and minor silt and mica. The change from one sediment size to the other is not gradational, rather it is fairly abrupt. Bases of hummocky sandstone sequences are erosive into underlying strata. Where a base is exposed over several tens of meters, contact of the hummocky sandstone sequence cuts into the underlying silty mudstone

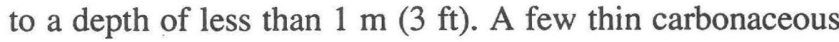
shale lenses also are present within the unit. These characteristics of hummocky crossbeds generally correspond with those observed by Bourgeois (1980), Hunter and Clifton (1982), and the model of Dott and Bourgeois $(1982,1983)$ that contains the four bedding types shown in figure 12 .

The lowermost hummocky crossbedded sandstone (unit 4) of the Big Sky section is underlain by massive to finely laminated sandstone that is faintly rippled, very fine grained sandstone (unit 3) and a similar lithology (unit 2) that contains some tiny mudchips. It is uncertain if units 2 and 3 are genetically related to the hummocky beds, but they display the same alternating buff and pale-green colors, and the same alternating compositional makeup, as the cross-laminated sandstone. These strata may represent two additional bedding types that Walker and others (1983) believed should be a part of the depositional model for hummocky crossbeds (fig. 12).

Bioturbated hummocky crossbedded sandstones (units 6 and 18) are poorly sorted and contain abundant organic debris. Most sedimentary structures have been destroyed, although a few hummocky crossbeds are preserved. Some of the hummocky sandstones intertongue with mudstone, showing that the cross stratification is an amalgamation of hummocky strata. Fossil debris is common in unit 18 and includes fish scales and fragments of Cyprimeria?; Inoceramus sp., possibly I. flaccidus White; an oyster fragment, possibly Pycnodonte; an ammonite, possibly Scaphites arcadiensis Moreman; and the longranging brachiopod Lingula subspatula Hall. Ophiomorpha is the only trace fossil that was identified.

\section{Interpretation}

Hummocky crossbedding commonly is attributed to oscillatory motion of storm waves (Harms and others, 1975; Bourgeois, 1980). The hummocky crossbedded sandstones of the Frontier are interpreted as deposits of the lower shoreface, where they were not reworked by fair-weather waves. Sandstone sequences with hummocky crossbedding are sharp based (erosional); whereas, the uppermost part of each sequence is gradational into overlying siltstone, or siltstone or mudstone strata. These data and the intense bioturbation in the uppermost part of sandstone sequences (units 8 and 19) suggest that the hummocky cross-stratified sandstones were deposited rapidly into an environment 


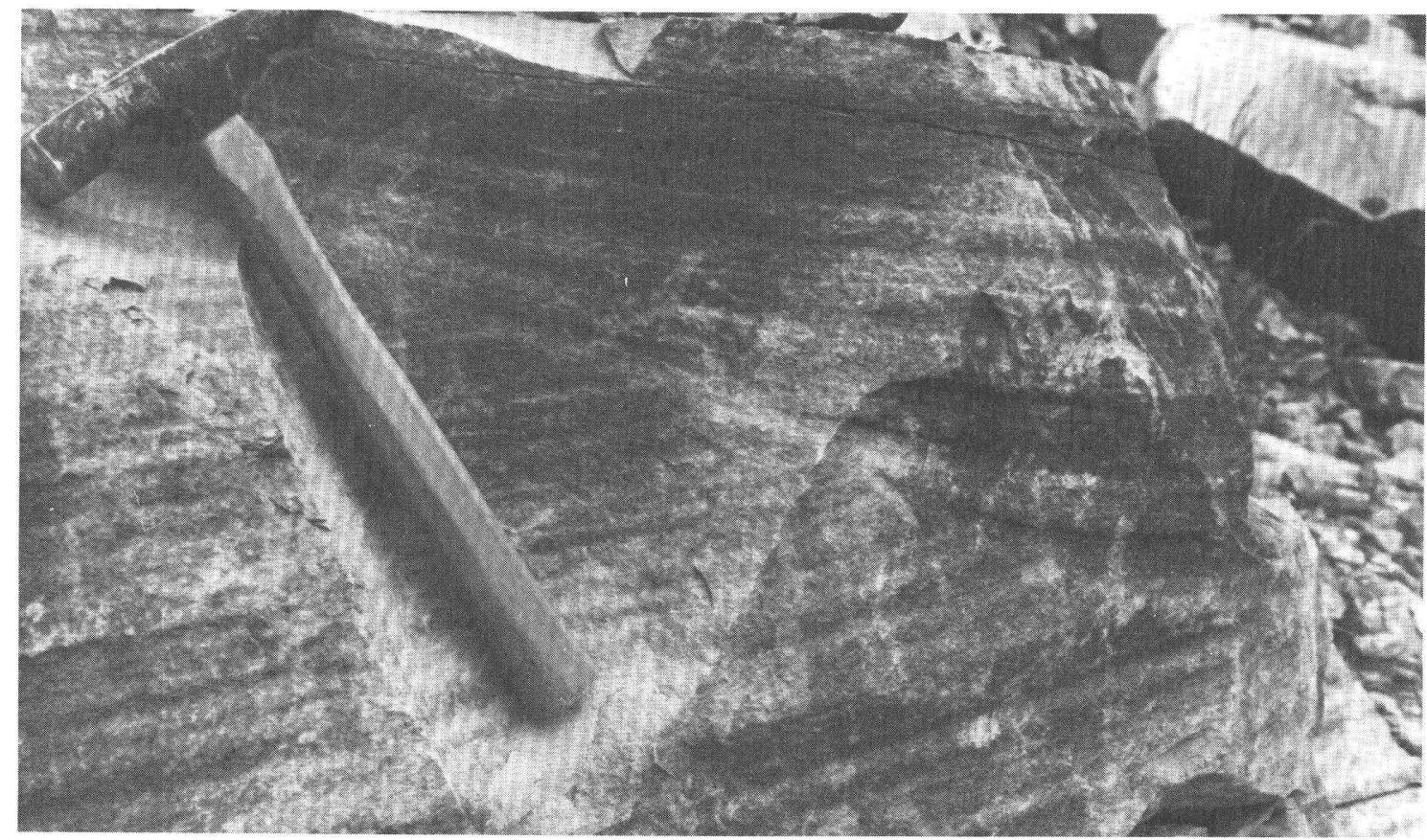

Figure 11. Hummocky cross-laminated sandstone of lithologic unit 6 . Hammer head is $20 \mathrm{~cm}$ ( $8 \mathrm{in}$.) long. Outcrop is in roadcut of Big Sky measured section, NE $1 / 4$ SE$^{1} / 4$ Sec. 28, T. 6 S., R. 3 E., Gallatin Peak 7.5-minute quadrangle.

TOP

\begin{tabular}{|c|c|c|}
\hline $\begin{array}{l}M \\
X \\
F \\
H\end{array}$ & $\begin{array}{l}\text { Mudstone } \\
\text { Cross laminae } \\
\text { Flat laminae } \\
\text { Hummocky zone }\end{array}$ & Model of Dott and Bourgeois (1982, 1983) \\
\hline $\begin{array}{l}P \\
B\end{array}$ & $\begin{array}{l}\text { Parallel laminae } \\
\text { Base, massive } \\
\text { or graded }\end{array}$ & $\begin{array}{l}\text { Walker and others (1983) proposed that this } \\
\text { part be added to model }\end{array}$ \\
\hline
\end{tabular}

BOTTOM

Figure 12. Sequence of sedimentary structures in hummocky crossbedded strata as determined by models of Dott and Bourgeois (1982, 1983) and Walker and others (1983).

normal for siltstone or mudstone-that is, hummocky sandstone is a storm deposit that accumulated seaward of where fair-weather sand deposition would have taken place. This interpretation agrees with the concept of storm generated hummocky beds espoused by Walker and others (1983), and Aigner (1985). Aigner interpreted proximal (near-shore) storm beds as thick bedded and coarse grained, and distal equivalents as mud-dominated and thin, oneevent beds. Proximal deposits should be more abundant and thicker than distal storm deposits, and they should show evidence of repeated reworking or amalgamation of several events and ecologic communities.

The thin hummocky sandstone beds in the prodelta strata of unit 21 represent single events. Strata above the single-event hummocky sandstone beds are siltstone or mudstone beds that lack hummocky sands and may have been deposited still farther offshore. (Alternatively, a cessation of storms or decrease in storm strength could produce the same sequence of siltstone or mudstone.)

Trace fossils present in the hummocky crossbeds are consistent with a lower shoreface depositional environment. In general, Ophiomorpha with vertical components ranges throughout the shoreface environment and into the foreshore-shoreface transition zone, and are indicative of relatively high levels of wave or current energy and shifting particulate substrates (Frey and Howard, 1985). In the Big Sky section, burrows of Ophiomorpha are present in virtually all of the hummocky cross-stratified sandstone units. Most of these probably were formed below fairweather wave base where they were not reworked by waves.

Upper shoreface and paralic sediments are absent from the hummocky strata in the Big Sky section and most likely never were deposited after the storm deposits were laid down-only lower shoreface sands ever existed. The existence of "thin" hummocky sandstone beds interbedded within the prodelta strata (described in the previous section) is a strong argument for this interpretation. Further, the occurrence of mudstone layers within the upper part of the hummocky sequences argues for a depositional environment of the lowermost lower shoreface of the delta front.

This interpretation contrasts with that of some workers (for example, Weise, 1980; Bourgeois, 1980), wherein coarsening-upward clastic sequences within deltas represent truncated sequences-that is, offshore and lower shoreface strata are present but upper shoreface, beach, and 
delta plain strata have been eroded. In this interpretation, upper shoreface and foreshore strata were reworked, destroyed, during marine transgressions that followed progradation. In the Big Sky section, I found no conglomerates, lag deposits of any kind, or other evidence of erosion or transgression at the top of the hummocky crossbeds or in the overlying prodelta strata, to support the concept of a truncated sequence.

\section{Bioturbated Muddy Fine-Grained Sandstone}

Bioturbated muddy fine-grained sandstone to siltstone (fig. 4, lithologic units 8 and 19) directly overlies hummocky crossbedded sandstone in a few places. The units are $1.5-3 \mathrm{~m}(5-10 \mathrm{ft})$ thick. The strata are rubbly weathering and lack laterally continuous laminae, although discontinuous shale or mudstone layers a few millimeters thick are present locally. The sandstone and siltstone is thoroughly bioturbated. Unit 19 definitely is gradational through 10-15 cm (4-6 in.) with underlying hummocky sandstone; mudstone or siltstone has been churned by infauna into the uppermost part of the sandstone. No specific trace fossils were identified from this unit.

\section{Interpretation}

These rocks are interpreted as deposits of the lowermost shoreface of the delta front facies or uppermost prodelta facies, deposited seaward of the bioturbated hummocky cross-stratified beds that lie directly beneath it. The thorough bioturbation reflects total, repeated reworking of sediments by infauna rather than absence of organisms; intense bioturbation also indicates slow, continuous rates of deposition (Frey and Howard, 1985).

\section{Delta Front Facies}

\section{Tabular and Trough Crossbedded Salt-and-Pepper Sandstone}

The upper 3-4 m (10-13 ft) of lithologic unit 25 (fig. 4) is pale-yellowish-gray, fine- to medium-grained, and locally coarse-grained and pebbly quartzose cherty sandstone. Tabular and trough crossbeds are abundant and are transitional into hummocky crossbedded sandstone that is present locally in the lower part of the unit. A few thin shale lenses are present in the upper strata. Strata of unit 25 are transitional into the sandstone of unit 26, which appears massive where freshly exposed in roadcuts, but displays gently dipping planar laminated beds where weathered. The sandstone of unit 26 is pale brown to light gray but weathers very light gray to white in an irregular zone $0.1-2.0 \mathrm{~m}$ $(0.3-7 \mathrm{ft})$ thick in its uppermost part. It is fine to medium grained and composed primarily of quartz, chert, and feldspar. Quartz grains range from subangular to well rounded. No heavy minerals, crossbeds, or burrow structures were observed in this unit.

\section{Interpretation}

The tabular and trough crossbeds and the wide range of grain sizes in the upper part of unit 25 are common in upper shoreface deposits (Reinson, 1984), or in the lowermost part of the foreshore (Frey and Howard, 1988). The better sorting and very low angle dip of thin, planar beds of unit 26 correspond to features typical of foreshore deposits as described, for example, by Harms and others (1975), Reinson (1984), and Frey and Howard (1988). The sandstone contains grains of a common size grading, but the mix of well-rounded to subangular grains reflects different sorting histories. The few percent of well-rounded quartz grains suggests either reworking of existing sandstone or an admix of windblown grains from dunes or other wind-sorted deposits onshore.

\section{Delta Plain Facies}

Strata of delta plain origin comprise a sequence of thin lithologic units, commonly a few centimeters to about

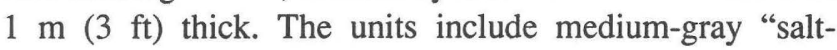
and-pepper" sandstone, dark-gray mudstone and siltstone; coaly and carbonaceous mudstone; and yellowish-green tuff, some of it weathered to mudstone that is light gray or reddish orange. The contact of the delta plain sequence with the underlying marine delta front deposits is marked by a general color contrast from light-gray sandstone of the delta front strata to the dark colors of much of the delta plain sequence.

\section{Bioturbated Salt-and-Pepper Sandstone}

Bioturbated sandstone of lithologic unit 27 (fig. 4) is about $0.5 \mathrm{~m}(1.5 \mathrm{ft})$ thick and is gradational with the sandstone of the underlying unit 26 , but unit 27 differs in that it mainly is composed of quartz, with only a few grains of chert and feldspar. Most of the quartz grains are angular to subangular, but 15-20 percent of them are well rounded, in contrast to a much smaller percentage of rounded grains in unit 26. Some of the well-rounded grains are frosted. In addition, sandstone of unit 27 contains some clay, giving it a medium-gray color, and is thoroughly bioturbated by plant roots. Unit 27 also contains abundant tubular fractures filled with a white noncalcareous material. A thin section shows a rootlet-like structure composed of carbonaceous material (charcoal?) that defines the two walls of the tubular structure; the structure was not disturbed by compaction. The thin section also shows isolated grains of the same carbonaceous material. 
Interpretation

The sandstone of unit 27 represents a backshore deposit, landward of the uppermost reach of waves of the foreshore environment. The association of angular to subangular and rounded grains, tubular root-like structures in vertical (growth) position, bioturbation by plants, and finely comminuted carbonaceous debris suggests deposition where the sand was stabilized by vegetation. Retallack (1988) described root traces in growth position as being one of the most diagnostic features of paleosols. The well-rounded quartz grains, particularly the frosted ones, are suggestive of a wind-blown origin, but the mix with angular grains indicates the preserved sandstone is not a dune.

\section{Carbonaceous Mudstone}

Dark-gray carbonaceous mudstone and coaly carbonaceous mudstone (fig. 4, lithologic units 31, 35, 37, 40,45 ) occur at several horizons in the delta plain strata of the Big Sky section. Lithologic unit 37 also contains a large percentage of clayey siltstone and is shown as siltstone in figure 4. The rest of the units are thin bedded and display very fine laminations. Burrowing is evident locally. A mudstone believed to part of unit 35 , but on the opposite side of the road from the measured section and not traceable across the road, yielded the freshwater clams Protelliptio n. sp. and Plesielliptio n. sp., and the freshwater snail Cairnarbis sp. The coaly carbonaceous mudstone of unit 37, which gradationally overlies carbonaceous clayey, crossbedded, siltstone of the unit, yielded crushed unionid bivalves. The fossils of both assemblages are disarticulated and abraded.

\section{Interpretation}

The coaly carbonaceous mudstone of unit 37 represents a heavily vegetated environment with little coarse clastic input. The carbonaceous material in the mudstone is not rooted but is debris that likely was transported into the depositional site. The unionid bivalves indicate the depositional site was a coastal freshwater swamp. The ripple crossbedded carbonaceous muddy siltstone of unit 37 could represent an overbank deposit or even a small delta where a stream debouched into the freshwater swamp.

The very fine laminations of carbonaceous strata of lithologic units $31,35,40$, and 45 record deposition in quiet water where only occasional wave and current action are characteristic, reducing conditions are common, and burrowing organisms exist. Fragmental accumulations of mollusks, which churned through sediment mixing sand and silt into adjoining clays, probably reflects wave action along a lake shore. The silty and sandy strata are not typical of lake sediments (Krinitzky and Smith, 1969) but represent a lacustrine delta where a stream entered a lake. These strata are much like those described and pictured by Coleman (1966), Krinitzsky and Smith (1969), and Krinitzsky (1970) from lake deposits of the Mississippi River delta plain, Louisiana.

The Plesielliptio sp. fauna of unit 35 indicate a freshwater lake environment. Shells of the fauna are disarticulated, but they are not severely abraded. The fauna could have lived in a paleoecological environment different from that indicated by the carbonaceous mudstone in which they were preserved, having been transported from a fluvial environment into a lake. Hanley (1976) found mollusks of the genera Plesielliptio sp. to occupy a fluvatile habitat near freshwater lakes and transported specimens were found in lakeshore sediments. Hanley and Flores (1987) found nontransported specimens of Plesielliptio were most common in very shallow water, near-shore lake settings, although the fauna also were found offshore in small lakes.

\section{Clayey Siltstone and Mudstone}

These strata (fig. 4, lithologic units $33,43,48$, and 50) are dark-gray clayey siltstone, black carbonaceous mudstone, and coaly mudstone. They contain abundant detrital plant debris. The mudstone appears massive. Unit 43 contains very small crystals of pyrite and dispersed 1-2 mm (0.04-0.08 in.) fragments of calcareous shell debris. Unit 33 consists of coaly mudstone that gradationally overlies siltstone containing small-scale ripple crossbeds. The coaly mudstone of unit 33 and the siltstone of unit 43 both yielded disarticulated, abraded shells of Brachiodontes sp., Anomia sp., and Corbula sp., which are brackish water genera.

\section{Interpretation}

The sedimentological and compositional features of these strata conform to those of poorly drained swamp deposits as described and pictured by Coleman (1966), Krinitzsky and Smith (1969) and Krinitzsky (1970). The carbonaceous material in the rock units is not rooted but is debris that likely was transported into the depositional site during floods. The faunal assemblage of units 33 and 43 are brackish water forms. The abraded and disarticulated fossils of both units could have been transported into their depositional sites or simply reworked within them.

\section{Tuff and Bentonite}

Tuff and bentonite are interstratified with the delta plain sequence and form beds $0.2-2.0 \mathrm{~m}(0.7-6.6 \mathrm{ft})$ thick. Tuff beds (fig. 4, lithologic units 30, 32, 34, 39, 43, and 49) are pale-greenish-gray to pale-yellowish-green. Some of the tuff beds are hard, due to silicification, and contain very small plagioclase phenocrysts. At least one of the beds is graded and contains lithophysae. Other tuffaceous beds are 
deeply weathered and are more properly called bentonite (fig. 4, lithologic units 28, 29, 31, 36, 38, and 44). The bentonite ranges from very light gray to reddish orange. $\mathrm{X}$-ray diffraction examination of two of the bentonites shows presence of montmorillonite clay. All colors of the tuff and bentonite contrast strongly with the dark grays of the carbonaceous clayey sandstone, siltstone, and mudstone of the sequence. Contacts of the tuff and bentonite beds with overlying and underlying strata are sharp. No root structures were observed in any of the tuff or bentonite beds, and no bioturbation-mixing of the tuff or bentonite with underlying or overlying dark-gray mudstone or siltstone was observed.

\section{Interpretation}

The characteristics displayed by the tuff and bentonite are consistent with their airfall deposition into shallow water lakes or swamps that lacked reworking by waves, and (or) on land that lay adjacent to the water bodies. Only one of the tuff beds in the Big Sky measured section showed convincing evidence of reworking by water. A $0.5 \mathrm{~m}(1.6 \mathrm{ft})$ thick bed of tuff about $13 \mathrm{~km}(8 \mathrm{mi})$ west-southwest of the Big Sky section definitely was deposited in water, as indicated by ball-and-pillow structures (fig. 13). Inundation of land adjacent to the water bodies during floods, or a relative rise in sea level, could account for accumulation of overlying deltaic sediments. The deep weathering of tuff to form bentonite may reflect oxidation shortly after the time of deposition, but such effects also could have taken place recently. No soil textures indicative of weathering shortly after deposition were observed.

\section{Laminated and Burrowed Sandstone}

Sandstone of lithologic unit 47 (fig. 4) is light gray, fine to medium grained, and composed of well-rounded and angular to subangular grains of quartz, some feldspar (chiefly potassium feldspar), and chert. In one location the sandstone is poorly sorted, contains wispy mudstone flasers, and is thoroughly burrowed. The main burrow structure is of the trace fossil Ophiomorpha irregulaire, which is filled almost entirely of carbonaceous mudstone. Also observed were a few burrows of Teichichnus, another horizontal trace fossil formed by a deposit-feeding animal.

In another location the sandstone is well sorted and displays parallel laminations. Rip-up mud clasts a few millimeters to about a centimeter across are associated with similar sized fragments of clams. Fragments of Crassostrea sp., an oyster, and Corbula sp., another bivalve, were found at this location. U-shaped burrows of the trace fossil Diplocraterion, a vertically oriented dwelling structure, were the only trace fossils found in these strata.

\section{Interpretation}

The depositional environment interpreted for this unit is a bay or lagoon, or partially enclosed distributary river

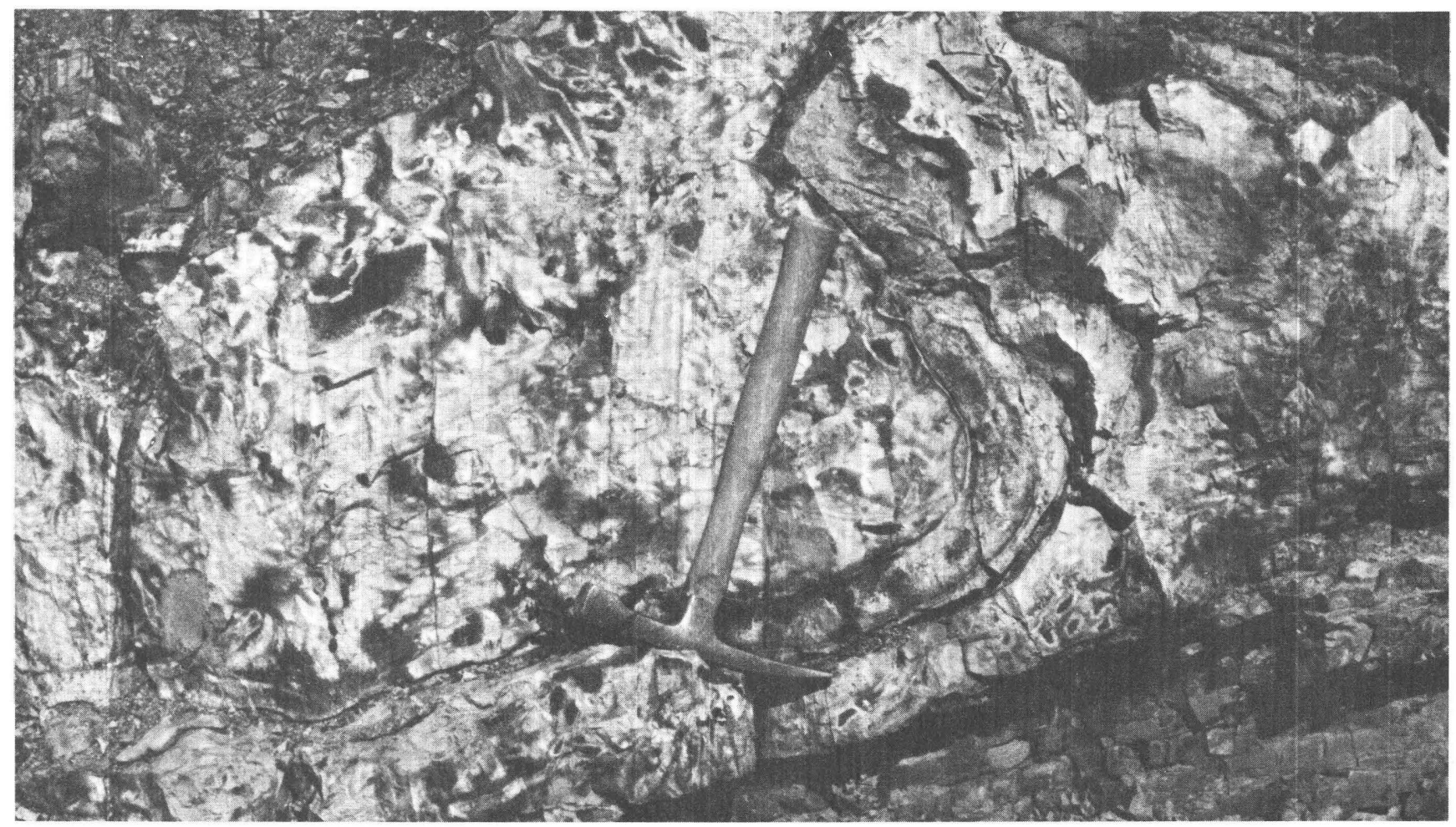

Figure 13. Pillow structure in tuff bed of delta plain strata in upper part of Frontier Formation. Outcrop is at head of Muddy Creek, $13 \mathrm{~km}(8 \mathrm{mi})$ southwest of the Big Sky measured section. Hammer handle is $30 \mathrm{~cm}(12 \mathrm{in.}$ ) long. 
mouth, such as at the seaward edge of the delta plain of the Niger delta where barrier spits restrict entrance to the rivers and form small estuaries that undergo tidal reversal (Allen, 1965). The low diversity of trace fossils, the horizontal versus vertical forms, the contrasting abundances of trace fossils, and the strata known to directly overlie and underlie the sandstone unit support this interpretation. An open marine setting likely would have produced a sandstone that differed little in the character of its ichnofauna from one place to another.

The sandstone of unit 47 contains contrasting types of trace fossils at two locations less than $0.8 \mathrm{~km}(0.5 \mathrm{mi})$ apart. The restriction of specific types of trace fossils to different areas of the same rock unit reflects contrasting environments. The $U$-shaped traces of Diplocraterion are indicative of a moderate to high energy environment. The traces are truncated by laminae of mudstone and carbonaceous debris indicating that the lamination of the sandstone records successive depositional events. The sediment and trace fauna are indicative of the Skolithos ichnofacies, which is characterized by moderate to high energy conditions and shifting sediments (Ekdale and others, 1984). In contrast, the area of the sandstone that is thoroughly bioturbated by the horizontal burrows of Ophiomorpha and Teichichnus indicates a moderate to low energy environment of the Cruizana ichnofacies. This mix of trace fauna representing the Skolithos and Cruizana ichnofacies at a locality is suggestive of a brackish water environment (Howard and Frey, 1985; Ekdale and others, 1984).

A tidal sand-flat in a protected back-barrier environment provides a likely depositional model for the sandstone and the trace fauna. The well-laminated, least burrowed area of the sandstone was deposited closest to the low tideline where it was subjected to continuous current and wave action. The extensively burrowed sandstone, with its mud flasers, is characteristic of a middle tidal flat (mixed flat) (Duc and Tye, 1987), which is commonly inhabited by abundant deposit-feeding organisms that rework the substrate and obscure the original bedding (Ekdale and others, 1984). Such an environmental setting characteristically contains only a few species that can adapt to the extreme variation of environmental conditions, although such species may occur in high densities (Ekdale and others, 1984; Benyon and others, 1988). The well-rounded quartz grains in the sandstone indicate deposition proximate to a beach or a dunes, either (or both) of which subsequently was eroded. Duc and Tye (1987) reported that back-barrier sand flats of Kiawah Island, South Carolina, periodically received washover material, including shell debris, which later was reworked. The stratigraphic position of unit 47 , within a delta plain sequence of lagoonal, swamp, and marsh deposits, is an appropriate setting for washover deposits (Hennessy and Zarillo, 1987).

\section{Claystone}

Claystone (fig. 4, lithologic unit 51) is pale gray green, massive, hard, and appears homogeneous in hand specimen. It lacks laminations or evidence of primary soil structures. Thin section examination shows a few widely dispersed silt grains, minor comminuted and dispersed organic debris, and bioturbation, perhaps by both plants and animals. The mottled, churned appearance visible in thin section suggests burrowing by animals. Later cross-cutting tubular structures probably are rootlets. The rootlets are filled with claystone of slightly different composition from that of the claystone outside the rootlets.

\section{Interpretation}

The claystone is interpreted to be a marsh deposit, displaying characteristics of modern marsh sediment described by Edwards and Frey (1977), Basan and Frey (1977), and Kosters (1989). These authors recognized three classes of marsh: low, transitional, and high. Unit 51 has the characteristics of the low marsh sediment. It is highly clayey silt to sandy mud that is essentially homogeneous, having been thoroughly reworked by animals and plant roots. Laminations are rare.

\section{Conglomerate, Sandstone, and Lenticular-Bedded Siltstone}

A ledge of conglomerate, sandstone, and lenticularbedded siltstone to mudstone forms a prominent finingupward sequence about $6.5 \mathrm{~m}(21 \mathrm{ft})$ thick at the top of the Big Sky measured section (fig. 14). The conglomerate forms a discontinous bed (fig. 4, lithologic unit 52) at the base of the sequence and is composed of well-rounded pebbles $0.5-6 \mathrm{~cm}(0.2-2.4 \mathrm{in}$.) in diameter in a sandstone matrix. The matrix is pale-brown, calcareous, fine- to coarse-grained sandstone that is mainly composed of angular to well-rounded quartz grains in mudstone. No shell fragments were found in the conglomerate. The pebbles consist of dark-gray chert (70 percent), light- to dark-gray quartzite ( 25 per cent), and other compositions (5 per cent). Some of the chert contains silicified pelmatazoan debris and is probably from the Mississippian Madison Group, but the major part of the chert likely is from the Permian Phosphoria (or Shedhorn) Formation. Pebbles from these formations also are present in pre-Frontier Mesozoic strata of the Madison Range. The pebbly sandstone is lenticular, ranges up to $15 \mathrm{~cm}$ (6 in.) thick, and extends for several meters along the strike of the outcrop. The base is erosional.

Sandstone (lithologic unit 53) directly overlies the

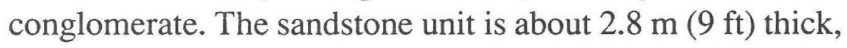
is ripple laminated and trough crossbedded, and contains interlayered discontinuous lenses of mudstone. Sandstone 




Figure 14. Tidal estuarine deposit of lithologic units 52 (covered), 53, and 54, underlain by mudstone of lithologic unit 51 (covered). Outcrop is in uppermost part of Big Sky measured section, along ridge crest in SW $1 / 4 \mathrm{NE}^{1} 1 / 4$ Sec. 28, T. 6 S., R. 3 E., Gallatin Peak 7.5-minute quadrangle.

beds are about $10-30 \mathrm{~cm}(4-12$ in.) thick, and the base of each commonly is erosional. The sandstone is fine grained and is composed of quartz, feldspar, and minor biotite; finely comminuted organic debris is common, but no shell material was found. A few horizontal burrows are present locally where the sandstone contains a large amount of mud. In the lower part of unit 53, mudstone makes up about 25 percent of the rock. Ripple cross-laminated sandstone layers $0.5-2 \mathrm{~cm}(1.3-5 \mathrm{in}$.) thick are separated by mudstone layers that are about $0.5 \mathrm{~cm}(0.4$ in.) thick. Some of the mud layers are drapes: they are present only at the toe of a cross lamina, decreasing in thickness and pinching out upward in the crossbed. Within areas of trough crossbeds, mainly in the upper part of unit 53, medium- to dark-gray mudstone alternates with sandstone. The mudstone content of the cross-laminated sandstone increases in the upper part of the trough, and in some places grades into horizontally laminated mudstone and silty mudstone that forms discontinuous lenses between trough cross-stratified sandstone beds. The lenses are as much as $15 \mathrm{~cm}$ (6 in.) thick and pinch and swell, both along and normal to strike. Some mudstone layers extend for several meters along strike, although most extend only a meter or two; their extent was not determined normal to strike owing to limited exposures. The lenses occur at irregular stratigraphic intervals and are overlain by sandstone beds that have erosional bases. Unit 53 is gradational into unit 54 .

Strata (unit 54) in the upper part of the ledge-forming sequence are $3.0 \mathrm{~m}(10 \mathrm{ft})$ thick and are composed of lenticular bedded mudstone and clayey siltstone. Locally discontinuous, isolated lenses of cross-laminated finegrained sandstone, the record of ripples that migrated across a mud substrate, are present within the mudstone. The sandstone layers are $0.1-1 \mathrm{~cm}(0.04-0.4 \mathrm{in}$.$) thick, and$ mudstone layers range up to $3 \mathrm{~cm}$ (1.2 in.) thick. The contact of sandstone and mudstone layers is sharp. The unit has been burrowed, but no identifiable forms were found. Molds of a few burrows, as much as $1 \mathrm{~cm}(0.4 \mathrm{in}$.) across 
and $5 \mathrm{~cm}$ ( 2 in.) long, were found weathered out on the ground surface and also were unidentifiable.

Upper strata of the lenticular-bedded unit yielded the following megafossils, reported previously by Tysdal and others (1990): Inoceramus lamarcki stumckei Heinz, and I. flaccidus White, which are clams; Rhynchostreon suborbiculatum (Lamarck), an oyster; Scaphites carlilensis Morrow, and Baculites sp., which are ammonites. The fossils are marine and marginal marine forms and constitute a late-middle Turonian assemblage. None of the clams, which constitute most of the specimens, were in growth position and all were disarticulated, consisting of large pieces of individual valves.

\section{Interpretation}

The sequence formed by lithologic units $52-54$ is interpreted as a tidal estuarine deposit because it has characteristics of the subtidal part of a point bar and because it contains a mixed assemblage of open marine and marginal marine fauna. It has characteristics of modern back-barrier tidal streams of the microtidal Niger delta. The upward changing sequence of intermittent lag gravel, interbedded cross-laminated sandstone and mudstone lenses, and overlying interbeds of siltstone and mudstone are characteristic of tidal estuarine deposits described by Howard and Frey (1985) in modern deposits of Georgia tidal estuaries that have rivers flowing into their headwaters.

Interbedded sandstone and mudstone constitute the most prominent feature of unit 53 and record contrasting depositional conditions. Rippled and trough cross-laminated sandstone reflect stronger current conditions than the laminated mudstone that contains horizontal trace fossils, which reflect weak currents. The laminated mudstone likely was deposited in the uppermost part of an estuary, or in a tidal stream that flowed into an estuary. In such a location, fine sediment settles out when water flow is inhibited by slack tides (Dorjes and Howard, 1975) and clay-silt floccules suspended in the brackish waters are deposited, forming cohesive muds that are difficult to erode (Allen, 1965). Thin clay beds occur throughout the cross-laminated sand of tidal channel deposits (Oomkens, 1974), and grainsize contrasts between the layers of tidal creeks are much more marked than in any other layered deposit in the Niger delta (Allen, 1965).

The upward fining of grain size of the Big Sky strata is reflected in the lenticular beds of unit 54 , which indicate decreasing transport power. The marine and marginal marine megafossils of these strata is an argument in support of a subtidal origin. These strata represent subtidal accretionary deposits.

None of the cross-laminated strata of unit 53 show rhythmically interlayering reflective of inequal diurnal tides, as reported by Visser (1980) in a mesotidal Dutch tidal flat. There, thin mud laminae form a couplet of two mud layers separated by a thin sandstone layer, each couplet separated by a thick sand layer called a tidal bundle. Such tidal bedding patterns have not been reported from microtidal environments, the tidal range commonly considered applicable to deposits of the Cretaceous Western Interior Sea. No herringbone crossbedding, indicative of reversing current flow, was found either.

\section{Contact Relationships of Facies in Big Sky Measured Section}

The relationship of the upper delta front strata at the top of the Lincoln Mountain measured section to the interbedded lower delta front and upper prodelta rocks of the Big Sky measured section is not known because the contact of the two sequences has not been observed at either location or elsewhere in the range. The lower Frontier strata are concealed in the area of Big Sky, and upper Frontier strata that are the time-equivalent of the Big Sky section have been eroded from the general area of Lincoln Mountain.

An unconformity occurs at the top of the Frontier in the Madison Range. Uppermost delta plain rocks of the Frontier are overlain by offshore (prodelta) mudstone of the Cody Shale, which contains late Coniacian megafossils. Several Western Interior molluscan fossil zones are unrepresented between the late-middle Turonian fauna at the top of the Frontier and the late Coniacian fauna of the basal Cody. The faunal and stratigraphic break correspond to the time of an unconformity recognized by Merewether and Cobban (1986) throughout northwestern Wyoming and adjacent southwestern and south-central Montana.

\section{CONCLUSIONS}

The section for the Frontier Formation in the Madison Range consists of two measured sequences that, combined, form a composite section. The lower part of the composite section, at Lincoln Mountain, consists of a regressive sequence of delta front strata that are overlain by delta plain strata. These rocks early Cenomanian rocks are separated by an unconformity from middle Turonian delta front deposits in the uppermost part of the Lincoln Mountain section. The upper part of the composite measured section, near Big Sky, consists of a regressive sequence of late-middle Turonian lower delta front hummocky crossbedded sandstone and intertonguing prodelta strata. This sequence is overlain by sandstone of the upper delta front (shoreface) and lower delta plain facies. The uppermost $25 \mathrm{~m}(82 \mathrm{ft})$ of the Big Sky section of the Frontier is interpreted as a delta plain sequence composed mainly of mudstone and siltstone. 


\section{REFERENCES CITED}

Aigner, Thomas, 1985, Storm depositional systems: New York, Springer-Verlag Publishing Company, $174 \mathrm{p}$.

Allen, J.R.L., 1965, Late Quaternary Niger delta, and adjacent areas; sedimentary environments and lithofacies: American Association of Petroleum Geologists Bulletin, v. 49, p. 547-600.

1982, Sedimentary structures, their character and physical basis, volume II: New York, Elsevier Scientific Publishing Company, $663 \mathrm{p}$.

Austin, W.H., and Stoever, E.C., Jr., 1950, Reconnaissance geology of the south flank of Cinnamon Mountain, Gallatin County, Montana: Ann Arbor, University of Michigan, M.S. thesis, $102 \mathrm{p}$.

Barwis, J.H., and Hayes, M.O., 1985, Antidunes on modern and ancient washover fans: Journal of Sedimentary Petrology, v. 55, p. 907-916.

Basan, P.B., and Frey, R.W., 1977, Actual-palaeontology and neoichnology of salt marshes near Sapelo Island, Georgia, in Crimes, T.P., and Harper, J.C., Trace fossils 2: Geological Journal Special Issue No. 9, Liverpool, England, Seahouse Press, p. 41-70.

Bates, R.L., and Jackson, J.A., eds., 1987, Glossary of geology (3d ed.): Alexandria, Virginia, American Geological Institute, $788 \mathrm{p}$.

Becraft, G.E., Kiilsgaard, T.H., and van Noy, R.M., 1970, Mineral resources of the Jack Creek Basin, Madison County, Montana: U.S. Geological Survey Bulletin 1319-B, 24 p.

Benyon, B.M., Pemberton, S.G., Bell, D.D., and Logan, C.A., 1988, Environmental implications of ichnofossils from the Lower Cretaceous Grand Rapids Formation, Cold Lake oil sands deposit, in James, D.P., and Leckie, D.A., eds., Sequences, stratigraphy, sedimentology-surface and subsurface: Canadian Society of Petroleum Geologists Memoir 15, p. 275-290.

Bolm, J.G., 1969, Geology of the Lone Mountain area, southwestern Montana: Moscow, University of Idaho, M.S. thesis, $38 \mathrm{p}$.

Bourgeois, Joanne, 1980, A transgressive shelf sequence exhibiting hummocky stratification: the Cape Sebastian Sandstone (Upper Cretaceous), southwestern Oregon: Journal of Sedimentary Petrology, v. 50, p. 681-702.

Chan, M.A., and Dott, R.H., Jr., 1986, Depositional facies and progradational sequences in Eocene wave-dominated deltaic complexes, southwestern Oregon: American Association of Petroleum Geologists Bulletin, v. 70, p. 415-429.

Cobban, W.A., and Kennedy, W.Q., 1989, The ammonite Metengonoceras Hyatt, 1903, from the Mowry Shale (Cretaceous) of Montana and Wyoming: U.S. Geological Survey Bulletin 1787-L, $23 \mathrm{p}$.

Coleman, J.M., 1966, Ecological changes in a massive fresh-water clay sequence: Transactions of Gulf Coast Association of Geological Societies, v. 15, p. 159-174.

Dorjes, Jurgen, and Howard, J.D., 1975, Estuaries of the Georgia coast, U.S.A.: sedimentology and biology. IV. Fluvialmarine transition indicators in an estuarine environment, Ogeechee River-Ossabaw sound: Senckenberiana Maritima, v. 7, p. 137-179.
Dott, R.A., Jr., and Bourgeois, Joanne, 1982, Hummocky stratification: significance of its variable bedding sequences: Geological Society of America Bulletin, v. 93, p. $663-680$.

1983, Hummocky stratification: significance of its variable bedding sequences: reply: Geological Society of America Bulletin, v. 94, p. 1249-1251.

Duc, A.W., and Tye, R.S., 1987, Evolution and stratigraphy of a regressive barrier/backbarrier complex; Kiawah Island, South Carolina: Sedimentology, v. 34, p. 237-251.

Dyman, T.S., Materna, W.L., and Wilcox, L.A., 1985, Stratigraphic applications of the Geologic Analysis System (GAS) [abs.]: American Association of Petroleum Geologists Bulletin, v. 69, p. 251.

Edwards, J.M., and Frey, R.W., 1977, Substrate characteristics within a Holocene salt marsh, Sapelo Island, Georgia: Senckenbergiana Maritima, v. 9, p. 215-259.

Ekdale, A.A., Bromley, R.G., and Pemberton, S.G., 1984, Ichnology-trace fossils in sedimentology and stratigraphy: Society of Economic Paleontologists and Mineralogists Short Course Notes No. 15, 317 p.

Frey, R.W., and Howard, J.S., 1985, Trace fossils from the Panther Member, Star Point Formation (Upper Cretaceous), Coal Creek Canyon, Utah: Journal of Paleontology, v. 59, p. $370-404$.

1988, Beaches and beach-related facies, Holocene barrier islands of Georgia: Geological Magazine, v. 6, p. 621-640.

Frey, R.W., Howard, J.D., and Pryor, W.A., 1978, Ophiomorpha; its morphologic, taxonomic, and environmental significance: Palaeography, Palaeoclimatology, Palaeocology, v.'23, p. 199-299.

Garihan, J.M., Schmidt, C.J., Young, S.W., and Williams, M.S., 1983, Geology and recurrent movement history of the Bismark-Spanish Peaks-Gardiner fault system, southwest Montana, in Lowell, J.D, ed., Rocky Mountain foreland basins and uplifts: Rocky Mountain Association of Geologists, p. 295-314.

Hadley, J.B., 1969, Geologic map of the Cameron quadrangle, Madison County, Montana: U.S. Geological Survey Geologic Quadrangle Map GQ-813, scale 1:62,500.

1980, Geology of the Varney and Cameron quadrangles, Madison County, Montana: U.S. Geological Survey Bulletin 1459, $108 \mathrm{p}$.

Hall, W.B., 1961, Geology of part of the upper Gallatin Valley of southwestern Montana: Laramie, University of Wyoming, Ph. D. thesis, 239 p.

Hanley, J.H., 1976, Paleosynecology of nonmarine Mollusca from the Green River and Wasatch Formations (Eocene), southwestern Wyoming and northwestern Colorado, in Scott, R.W., and West, R.R., eds., Structure and classification of paleocommunities: Stroudsburg, Pennsylvania, Dowden, Hutchinson, and Ross, Inc., p. 235-261.

Hanley, J.H., and Flores, R.M., 1987, Taphonomy and paleoecology of nonmarine Mollusca; indicators of alluvial plain lacustrine sedimentation, upper part of the Tongue River Member, Fort Union Formation (Paleocene), northern Powder River basin, Wyoming and Montana: Palaios, v. 2, p. $479-496$. 
Harms, J.C., Southard, J.B., Spearing, D.R., and Walker, R.G., 1975, Depositional environments as interpreted from primary sedimentary structures and stratification sequences: Society of Economic Paleontologists and Mineralogists Short Course Notes No. 2, 161 p.

Harms, J.C., Southard, J.B., and Walker, R.G., 1982, Structure and sequences in clastic rocks: Society of Economic Paleontologists and Mineralogists Short Course Notes No. 9, $249 \mathrm{p}$.

Hayes, M.O., 1967, Hurricanes as geological agents; case studies of Hurricanes Carla, 1961, and Cindy, 1963: Texas Bureau of Economic Geology, Report of Investigations No. 61, $54 \mathrm{p}$.

Hennessy, J.T., and Zarillo, G.A., 1987, The interrelation and distinction between flood-tidal and washover deposits in a transgressive barrier island: Marine Geology, v. 78, p. 35-56.

Howard, J.D., and Frey, R.W., 1975, Estuaries of the Georgia coast, U.S.A.; sedimentology and biology. II. Regional animal-sediment characteristics of the Georgia estuaries: Senckenbergiana Maritima, v. 7, p. 33-103.

1985, Physical and biological aspects of back barrier sedimentary sequences, Georgia coast, U.S.A.: Marine Geology, v. 63, p. 77-127.

Howard, J.D., and Lohrengel, C.F., 1969, Large non-tectonic deformational structures from Upper Cretaceous rocks of Utah: Journal of Sedimentary Petrology, v. 39, p. $1032-1039$.

Hubert, J.F., Butera, J.G., and Rice, R.F., 1972, Sedimentology of Upper Cretaceous Cody-Parkman delta, southwestern Powder River basin, Wyoming: Geological Society of America Bulletin, v. 83, p. 1649-1670.

Hunter, R.E., and Clifton, H.E., 1982, Cyclic deposits and hummocky cross-stratification of probable storm origin in Upper Cretaceous rocks of the Cape Sebastian area, southwestern Oregon: Journal of Sedimentary Petrology, v. 52, p. 127-143.

Kehew, A.E., 1971, Environmental geology of part of the West Fork basin, Gallatin County, Montana: Bozeman, Montana State University, M.S. thesis, 58 p.

Kosters, E.C., 1989, Organic-clastic facies relationships and chronostratigraphy of the Barataria interlobe basin, Mississippi delta plain: Journal of Sedimentary Petrology, v. 59, p. 98-113.

Krinitzsky, E.L., 1970, Correlation of the backswamp sediments, Atchafalaya test section VI, Atchafalaya levee system, Louisiana: U.S. Army Engineer Waterways Experiment Station, Vicksburg, Mississippi, Technical Report S-70-2, $18 \mathrm{p}$.

Krinitzsky, E.L., and Smith, F.L., 1969, Geology of backswamp deposits in the Atchafalaya basin, Louisiana: U.S. Army Engineer Waterways Experiment Station, Vicksburg, Mississippi, Technical Report S-69-8, 58 p.

Lauer, J.C., 1967, The stratigraphy and structure of the Snowflake Ridge area, Gallatin County, Montana: Corvallis, Oregon State University, M.S. thesis, 165 p.
Leckie, D.A., and Walker, R.W., 1982, Storm- and tide-dominated shorelines in Cretaceous Moosebar-lower Gates interval-outcrop equivalents of deep basin gas trap in western Canada: American Association of Petroleum Geologists Bulletin, v. 66, p. 138-157.

McGookey, D.P., Haun, J.D., Hale, L.A., Goodell, H.G., McCubbin, D.G., Weimer, R.W., and Wulf, G.R., 1972, Cretaceous system, in Geologic Atlas of the Rocky Mountain region: Denver, Rocky Mountain Association of Geologists, p. 190-228.

Merewether, E.A., and Cobban, W.A., 1986, Biostratigraphic units and tectonism in the mid-Cretaceous foreland of Wyoming, Colorado, and adjoining areas, in Peterson, J.A., ed., Paleotectonics and sedimentation: American Association of Petroleum Geologists Memoir 41, p. 443-468.

Newman, W.S., and Munsart, C.A., 1968, Holocene geology of the Wachapreague Lagoon, Eastern Shore Peninsula, Virginia: Marine Geology, v. 6, p. 81-105.

Oomkens, Eppo, 1974, Lithofacies relations in the Late Quaternary Niger delta: Sedimentology, v. 21, p. 195-222.

Peale, A.C. 1896, Description of the Three Forks sheet (Montana): U.S. Geological Survey Atlas, Folio 24, 10 p.

Petroleum Information Corporation, 1984, Geologic Analysis System (GAS): Denver, Colo., Petroleum Information Corporation, Technical Services Training Manual, 195 p.

Ray, J.D., 1967, Structure and stratigraphy of the Cinnamon Mountain area, Gallatin County, Montana: Corvallis, Oregon State University, M.S. thesis, 148 p.

Reinson, G.E., 1984, Barrier-island and associated strand-plain systems, in Walker, R.G., ed., Facies models, second edition: Geological Association of Canada, Geoscience Canada Reprint Series 1, p. 119-140.

Retallack, G.J., 1988, Field recognition of paleosols, in Reinhardt, Jurgen, and Sigleo, W.R., eds., Paleosols and weathering through geologic time: Geological Society of America Special Paper 216, p. 1-20.

Rose, R.R., 1967, Stratigraphy and structure of part of the southern Madison Range, Madison and Gallatin Counties, Montana: Corvallis, Oregon State University, M.S. thesis, 172 p.

Schwartz, R.K., 1972, Stratigraphic and petrographic analysis of the Lower Cretaceous Blackleaf Formation, southwestern Montana: Bloomington, Indiana University, $\mathrm{Ph}$. D. thesis, $268 \mathrm{p}$.

1981, Nature and genesis of some storm washover deposits, in Leatherman, S.P., ed., Overwash processes: Stroudsburg, Pa., Hutchinson Ross Publishing Co., Benchmark Papers in Geology, No. 58, p. 229-260.

Shepard, F.P., and Moore, D.G., 1955, Central Texas coast sedimentation; characteristics of sedimentary environment, recent history, and diagenesis: American Association of Petroleum Geologists Bulletin, v. 39, p. 1463-1593.

Swanson, R.W., 1950, Geology of a part of the Virginia City and Eldridge quadrangles, Montana: U.S. Geological Survey Open-File Report, Spokane, Washington, $12 \mathrm{p}$.

Swift, D.J.P., Hudelson, P.M., Brenner, R.L., and Thompson, Peter, 1987, Shelf construction in a foreland basin: storm beds, shelf sand bodies, and shelf-slope depositional sequences in the Upper Cretaceous Mesaverde Group, Book Cliffs, Utah: Sedimentology, v. 34, p. 423-457. 
Thorbjarnarson, K.W., Nittrouer, C.A., DeMaster, D.J., and McKinney, R.B., 1985, Sediment accumulation in a backbarrier lagoon, Great Sound, New Jersey: Journal of Sedimentary Petrology, v. 55, p. 856-863.

Tysdal, R.G., 1990, Geologic map of the Sphinx Mountain quadrangle and adjacent parts of the Cameron and Hebgen Dam quadrangles, Montana: U.S. Geological Survey Miscellaneous Investigations Series Map I-1815, scale $1: 62,500$.

Tysdal, R.G., Dyman, T.S., and Nichols, D.J., 1989a, Correlation chart of Lower Cretaceous rocks, Madison Range to Lima Peaks area, southwestern Montana: U.S. Geological Survey Miscellaneous Field Studies Map MF-2067, 16 p. pamphlet.

1989b, Lower Cretaceous bentonitic strata in southwestern Montana assigned to Vaughn Member of Mowry Shale (east) and of Blackleaf Formation (west): Mountain Geologist, v. 26, p. 53-61.

Tysdal, R.G., Dyman, T.S., Nichols, D.J., and Cobban, W.A., 1990, Correlation chart of Frontier Formation from Greenhorn Range, southwestern Montana, to Mount Everts in Yellowstone National Park, Wyoming: U.S. Geological Survey Miscellaneous Field Studies Map MF-2116, 16 p. pamphlet.

Tysdal, R.G., and Simons, F.S., 1985, Geologic map of the Madison Roadless Area, Gallatin and Madison Counties, Montana: U.S. Geological Survey Miscellaneous Field Studies Map MF-1605-B, with text, scale 1:96,000.
Visser, M.J., 1980, Neap-spring cycles reflected in Holocene subtidal large-scale bedform deposits; a preliminary note: Geology, v. 8, p. 543-546.

Vuke, S.M., 1982, Depositional environments of the Cretaceous Thermopolis, Muddy and Mowry Formations, southern Madison and Gallatin Ranges, Montana: Missoula, University of Montana, M.S. thesis, $141 \mathrm{p}$.

1984, Depositional environments of the Early Cretaceous Western Interior Seaway in southwestern Montana and the northern United States, in Stott, D.F., and Glass, D.J., eds., The Mesozoic of Middle North America: Canadian Society of Petroleum Geologists Memoir 9, p. 127-144.

Walker, R.W., Duke, W.L., and Leckie, D.A., 1983, Hummocky stratification: significance of its variable bedding sequences: discussion: Geological Society of America Bulletin, v. 94, p. 1245-1249.

Walsh, T.H., 1971, Quaternary geology of the east portion of West Fork basin, Gallatin County, Montana: Bozeman, Montana State University, M.S. thesis, 83 p.

Warme, J.E., 1971, Paleoecological aspects of a modern coastal lagoon: University of California Publications in Geological Sciences, v. 87, p. 1-131.

Weise, B.R., 1980, Wave-dominated delta system of the Upper Cretaceous San Miguel Formation, Maverick basin, south Texas: Texas Bureau of Economic Geology Report of Investigations No. $107,39 \mathrm{p}$.

Wilson, M.D., 1970, Cretaceous stratigraphy of the southern Gallatin and Madison Ranges: Moscow, University of Idaho, $\mathrm{Ph}$. D. thesis, $86 \mathrm{p}$. 


\section{SELECTED SERIES OF U.S. GEOLOGICAL SURVEY PUBLICATIONS}

\section{Perlodicals}

Earthquakes \& Volcanoes (issued bimonthly).

Preliminary Determination of Epicenters (issued monthly).

\section{Technical Books and Reports}

Professional Papers are mainly comprehensive scientific reports of wide and lasting interest and importance to professional scientists and engineers. Included are reports on the results of resource studies and of topographic, hydrologic, and geologic investigations. They also include collections of related papers addressing different aspects of a single scientific topic.

Bulletins contain significant data and interpretations that are of lasting scientific interest but are generally more limited in scope or geographic coverage than Professional Papers. They include the results of resource studies and of geologic and topographic investigations; as well as collections of short papers related to a specific topic.

Water-Supply Papers are comprehensive reports that present significant interpretive results of hydrologic investigations of wide interest to professional geologists, hydrologists, and engineers. The series covers investigations in all phases of hydrology, including hydrogeology, availability of water, quality of water, and use of water.

Circulars present administrative information or important scientific information of wide popular interest in a format designed for distribution at no cost to the public. Information is usually of short-term interest.

Water-Resources Investigations Reports are papers of an interpretive nature made available to the public outside the formal USGS publications series. Copies are reproduced on request unlike formal USGS publications, and they are also available for public inspection at depositories indicated in USGS catalogs.

Open-File Reports include unpublished manuscript reports, maps, and other material that are made available for public consultation at depositories. They are a nonpermanent form of publication that may be cited in other publications as sources of information.

\section{Maps}

Geologic Quadrangle Maps are multicolor geologic maps on topographic bases in 7 1/2-or 15-minute quadrangle formats (scales mainly $1: 24,000$ or $1: 62,500$ ) showing bedrock, surficial, or engineering geology. Maps generally include brief texts; some maps include structure and columnar sections only.

Geophysical Investigations Maps are on topographic or planimetric bases at various scales; they show results of surveys using geophysical techniques, such as gravity, magnetic, seismic, or radioactivity, which reflect subsurface structures that are of economic or geologic significance. Many maps include correlations with the geology.

Miscellaneous Investigations Series Maps are on planimetric or topographic bases of regular and irregular areas at various scales; they present a wide variety of format and subject matter. The series also includes 71/2-minute quadrangle photogeologic maps on planimetric bases which show geology as interpreted from aerial photographs. Series also includes maps of Mars and the Moon.
Coal Investigations Maps are geologic maps on topographic or planimetric bases at various scales showing bedrock or surficial geology, stratigraphy, and structural relations in certain coal-resource areas.

Oil and Gas Investigations Charts show stratigraphic information for certain oil and gas fields and other areas having petroleum potential.

Miscellaneous Field Studies Maps are multicolor or black-andwhite maps on topographic or planimetric bases on quadrangle or irregular areas at various scales. Pre-1971 maps show bedrock geology in relation to specific mining or mineral-deposit problems; post-1971 maps are primarily black-and-white maps on various subjects such as environmental studies or wilderness mineral investigations.

Hydrologic Investigations Atlases are multicolored or black-andwhite maps on topographic or planimetric bases presenting a wide range of geohydrologic data of both regular and irregular areas; principal scale is $1: 24,000$ and regional studies are at $1: 250,000$ scale or smaller.

\section{Catalogs}

Permanent catalogs, as well as some others, giving comprehensive listings of U.S. Geological Survey publications are available under the conditions indicated below from the U.S. Geological Survey, Books and Open-File Reports Section, Federal Center, Box 25425, Denver, CO 80225 . (See latest Price and Availability List.)

"Publications of the Geological Survey, 1879-1961" may be purchased by mail and over the counter in paperback book form and as a set of microfiche.

"Publications of the Geological Survey, 1962-1970" may be purchased by mail and over the counter in paperback book form and as a set of microfiche.

"Publications of the U.S. Geological Survey, 1971-1981" may be purchased by mail and over the counter in paperback book form (two volumes, publications listing and index) and as a set of microfiche.

Supplements for 1982, 1983, 1984, 1985, 1986, and for subsequent years since the last permanent catalog may be purchased by mail and over the counter in paperback book form.

State catalogs, "List of U.S. Geological Survey Geologic and Water-Supply Reports and Maps For (State)," may be purchased by mail and over the counter in paperback booklet form only

"Price and Avallability List of U.S. Geological Survey Publications," issued annually, is available free of charge in paperback booklet form only.

Selected coples of a monthly catalog "New Publications of the U.S. Geological Survey" available free of charge by mail or may be obtained over the counter in paperback booklet form only. Those wishing a free subscription to the monthly catalog "New Publications of the U.S. Geological Survey" should write to the U.S. Geological Survey, 582 National Center, Reston, VA 22092.

Note.--Prices of Government publications listed in older catalogs, announcements, and publications may be incorrect. Therefore, the prices charged may differ from the prices in catalogs, announcements, and publications. 


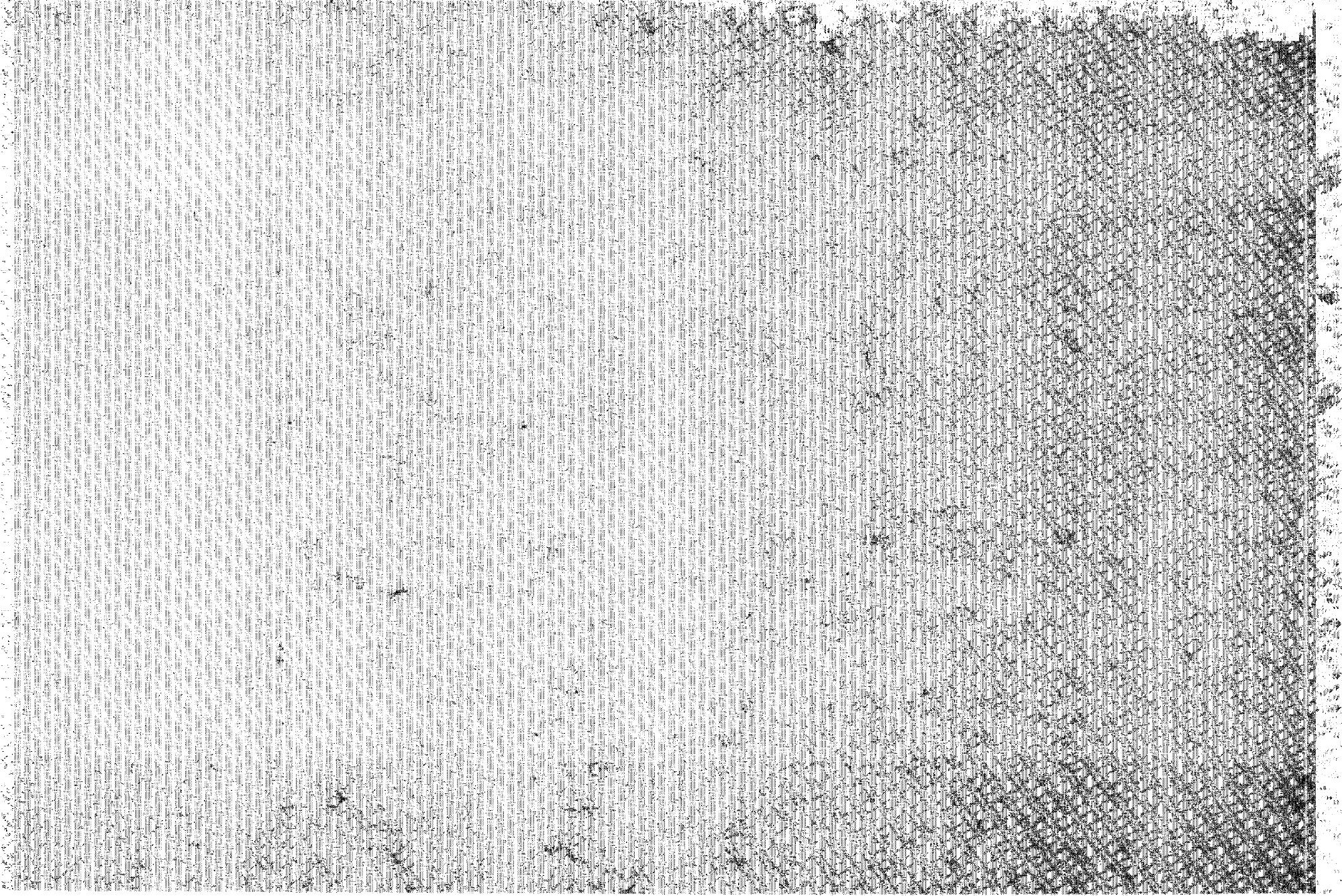

